OPEN ACCESS

Edited by: Concepcion Calvo, University of Granada, Spain

Reviewed by: Lal Singh,

National Environmental Engineering Research Institute (CSIR), India Vineet Kumar Guru Ghasidas Vishwavidyalaya, India

${ }^{*}$ Correspondence: Ales Hanc hanc@af.czu.cz

Specialty section:

This article was submitted to Microbiotechnology, a section of the journal

Frontiers in Microbiology

Received: 24 October 2021 Accepted: 23 November 2021

Published: 10 January 2022

Citation:

Hanc A, Dume B and Hrebeckova T (2022) Differences

of Enzymatic Activity During Composting and Vermicomposting of Sewage Sludge Mixed With Straw Pellets. Front. Microbiol. 12:801107. doi: 10.3389/fmicb.2021.801107

\section{Differences of Enzymatic Activity During Composting and Vermicomposting of Sewage Sludge Mixed With Straw Pellets}

\author{
Ales Hanc*, Bayu Dume and Tereza Hrebeckova \\ Department of Agroenvironmental Chemistry and Plant Nutrition, Faculty of Agrobiology, Food and Natural Resources, \\ Czech University of Life Sciences, Prague, Czechia
}

The study aims were focused on profiling eight hydrolytic enzymes by fluorescence method using a multifunctional modular reader and studying the proportion of basic microorganism groups during composting and vermicomposting of sewage sludge mixed with straw pellets in several proportions (0, 25, 50, 75, and 100\%). The greatest decrease in enzymatic activity occurred in the first half of composting and vermicomposting. After 4 months of these processes, the least enzymatic activity was observed in the sludge with 50\% and also 25\% straw addition, indicating that straw is an important means for the rapid production of mature compost from sewage sludge. Enzymatic activity was usually less in the presence of earthworms than in the control treatment because some processes took place in the digestive tract of the earthworm. For the same reason, we observed reduced enzyme activity during fresh feedstock vermicomposting than precomposted material. The final vermicompost from fresh feedstocks exhibited less microbial biomass, and few fungi and G- bacteria compared to precomposted feedstock. The enzymatic activity during composting and vermicomposting of sewage sludge and their mixtures stabilized at the following values: $\beta$-D-glucosidase-50 $\mu \mathrm{mol}$ MUFG/h/g dw, acid phosphatase-200 $\mu \mathrm{mol} \mathrm{MUFP} / \mathrm{h} / \mathrm{g}$ $\mathrm{dw}$, arylsulphatase-10 $\mu \mathrm{mol} \mathrm{MUFS} / \mathrm{h} / \mathrm{g} \mathrm{dw}$, lipase-1,000 $\mu \mathrm{mol} \mathrm{MUFY} / \mathrm{h} / \mathrm{g} \mathrm{dw}$, chitinase -50 $\mu \mathrm{mol}$ MUFN/h/g dw, cellobiohydrolase-20 $\mu \mathrm{mol} \mathrm{MUFC} / \mathrm{h} / \mathrm{g} \mathrm{dw}$, alanine aminopeptidase-50 $\mu \mathrm{mol}$ AMCA $/ \mathrm{h} / \mathrm{g} \mathrm{dw}$, and leucine aminopeptidase-50 $\mu \mathrm{mol}$ $\mathrm{AMCL} / \mathrm{h} / \mathrm{g} \mathrm{dw}$. At these and lesser values, these final products can be considered mature and stable.

Keywords: enzymatic activity, sewage sludge, straw pellets, composting, vermicomposting, microorganisms, earthworms

\section{INTRODUCTION}

The global production of sewage sludge is estimated at 45 million tons per year [expressed in dry matter (Zhang et al., 2017)]. The most common methods of handling dewatered treated sludge include direct application to agricultural land, landfilling, and composting. In the Czechia, sludge production was 228 thousand tons of dry matter in 2018, i.e., $21 \mathrm{~kg}$ per capita. Approximately $1 / 3$ of this amount was composted (Eurostat, 2021). 
The course of the composting process and the physicochemical and biological parameters of the final compost are especially affected by the addition of various bulking agents (Wang et al., 2021). Sludge composting with many bulking agents was previously described, e.g., sawdust, coffee husks, and brewery waste (Manga et al., 2021), yard trimming wastes (Robledo-Mahón et al., 2020), and cornstalks (Yuan et al., 2016). Composting is characterized by a thermophilic phase and the need to turn over or to aerate the composted material. Conversely, vermicomposting requires that the temperature does not exceed $35^{\circ} \mathrm{C}$, in which case the earthworms die. The optimal temperature is between 20 and $25^{\circ} \mathrm{C}$. Aeration is provided directly by earthworms by creating passages in the material. Earthworms act as mechanical blenders, and by disintegrating the organic matter, they change its physical and chemical properties, especially by gradually reducing the C:N ratio and increasing the surface area exposed to microorganisms. Thus, earthworms make feedstocks much more favorable for microbial activity and further decomposition (Dominguez and Edwards, 2011). At first, ingestion, digestion, assimilation, and the influence of earthworm gut microorganisms are involved in organic matter decomposition, and the processes associated with casting follow (Gómez-Brandón et al., 2011). Casting processes are more closely related to aging in maturation phase when the vermicompost is expected to reach optimum levels in terms of its biological parameters, thereby promoting plant growth and suppressing plant diseases. Little is known about determining the optimum levels (Domínguez and GómezBrandón, 2012). Degradation or utilization of substrate by microorganisms involves significant processes like nutrient cycling and transforming organic matter.

In the process, microbial activity could be assessed effectively with the analysis of enzymatic activity and microbial respiration. Soil enzyme activities provide information on the potential of soils to perform biochemical reactions (Błońska et al., 2017; Uzarowicz et al., 2020). Enzymatic activity was also explored as a possible tool for compost characterization and determination of compost maturity (Mondini et al., 2004). The biochemical reactions are brought about by enzyme catalytic action. Enzymes are divided into seven classes based on the reaction type that they catalyze, namely:

- Oxidoreductases-acting on the $\mathrm{CH}-\mathrm{OH}$ group of donors, the aldehyde or oxo group of donors, $\mathrm{CH}-\mathrm{CH}$ group of donors, $\mathrm{CH}-\mathrm{NH}_{2}$ group of donors, $\mathrm{CH}-\mathrm{NH}$ group of donors, etc.

- Transferases-transferring one-carbon groups, aldehyde, or ketonic groups, alkyl or aryl groups, other than methyl groups, nitrogenous groups, phosphorus-containing groups, etc.

- Hydrolases-acting on ester bonds, ether bonds, peptide bonds, carbon-nitrogen bonds, carbon-carbon bonds, phosphorus-nitrogen bonds, carbon-sulfur bonds, etc.

- Lyases-e.g., carbon-carbon lyases, carbon-oxygen lyases, carbon-nitrogen lyases, carbon-phosphorus lyases.

- Isomerases-e.g., racemases and epimerases, intramolecular isomerases and lyases.
- Ligases-forming carbon-oxygen bonds, carbon-sulfur bonds, carbon-nitrogen bonds, etc.

- Translocases-catalyzing the translocation of hydrons, inorganic cations, inorganic anions and their chelates, etc. (Nomenclature Committee of the International Union of Biochemistry and Molecular Biology [NC-IUBMB], 2021).

Some enzymes are important in organic material decomposition, organic matter transformation, nutrient cycling, nitrogen fixation, detoxification of hazardous substances such as xenobiotics, pesticides, pharmaceutical and personal care products, etc., and thus regulate the ecosystem (Gunjal et al., 2019). We studied eight hydrolase enzymes because they participate in metabolic processes during organic matter decomposition. These are as follows:

- $\beta$-glucosidase is widely distributed in nature and is related to the carbon cycle, acting in the cleavage of cellobiose into glucose molecules. Because of its sensitivity, this enzyme is considered as soil quality indicator and is directly related to the quantity and quality of soil organic matter. Furthermore, the addition of soil organic residues, such as biosolids, manure, urban sludge, and poultry litter, increases the activity of this enzyme in soil (Almeida et al., 2015). A long-term field experiment utilizing barley received four different treatments prior to sowing: municipal solid waste compost at either $20 \mathrm{t} / \mathrm{ha}$ (C20) or $80 \mathrm{t} / \mathrm{ha}$ (C80), cow manure at $20 \mathrm{t} / \mathrm{ha}$ (MA), and mineral fertilizer either NPK $400 \mathrm{~kg} / \mathrm{ha}$ or $\mathrm{NH}_{4} \mathrm{NO}_{3} 150 \mathrm{~kg} / \mathrm{ha}$ (MIN). The enzymatic activity of $\beta$-glucosidase was higher by $38,62,87$, and $6 \%$ for C20, C80, MA, and MIN, respectively, compared with control unfertilized variant (García-Gil et al., 2000).

- Acid phosphatase-Phosphate-solubilizing microorganisms are crucial for the transformation of organically bounded phosphorus into bioavailable forms by excreting extracellular phosphatase in the form of acid and alkaline phosphatase (Zheng et al., 2021).

- Arylsulphatase hydrolyzes aromatic sulfate esters and releases $\mathrm{SO}_{4}{ }^{2-}$. It is an indicator of sulfur mineralization in soils and also is important in the cycling of this element (Uzarowicz et al., 2020).

- Lipases are ubiquitous enzymes that catalyze the breakdown of fats and oils with the subsequent release of free fatty acids, diacylglycerols, monoglycerols, and glycerol. Besides this, they are also efficient in various reactions, such as esterification, transesterification, and aminolysis, in organic solvents. Therefore, those enzymes are nowadays extensively studied for their potential industrial applications. Examples in the literature concerning their use in different fields are numerous, such as resolution of racemic mixtures, synthesis of new surfactants and pharmaceuticals, oil and fat bioconversion, and detergency applications (Villeneuve et al., 2000).

- Chitinases are able to degrade the chitin chain. Chitinases are classified as exochitinases or endochitinases. Exochitinases cleave chitin from the open ends, while 
endochitinases cleave chitin at random positions. Fungal chitinases belong to the glycoside hydrolase family 18 and are divided into three phylogenetic groups-A, B, and Cand further subdivided into several subgroups. Chitinases are involved in different aspects of fungal biology, including fungal-fungal interactions, nutrient acquisition, cell wall remodeling, and autolysis (Tzelepis and Karlsson, 2021).

- Cellobiohydrolases are among the most important enzymes functioning in crystalline cellulose hydrolysis, significantly contributing to the efficient biorefining of recalcitrant lignocellulosic biomass into biofuels and bio-based products. Filamentous fungi are recognized as both well-known producers of cellulolytic enzyme commercial preparations and efficient hosts for heterologous protein secretion (Zoglowek et al., 2015).

- Aminopeptidases belong to exopeptidases, proteolytic enzymes that remove amino acids from the termini of peptides and proteins. They attack their substrates exclusively from the amino terminal end. Most remove one amino acid at a time, but a small group cleaves two or three residues. Alanine and leucine aminopeptidases release terminal nitrogen from amino acids (mainly from alanine and leucine), peptides, amides, and arylamides (Bradshaw, 2013).

Commercially derived hydrolytic enzymes are very expensive, whereas enzymes produced from mixed biosolids are very cheap and perform similarly to commercially produced enzymes (Nabarlatz et al., 2012). Enzymes secreted by microbial species or commercially produced enzymes were used in biosolid pretreatment for increasing methane production (Sethupathy et al., 2020).

In the literature, there are hydrolytic enzyme activity values, which were determined by classical colorimetric methods. We used a fluorescence method with multifunctional modular reader, which is a fast, modern, and economically advantageous method for determining the enzymatic activity in a large sample number. The enzymatic activity trends and values of eight hydrolytic enzymes identified in this study can be a guide for research and control institutes and for producers of composts and vermicomposts based on sewage sludge. The values can be used to predict compost and vermicompost maturity and to determine the time when the enzymatic activity no longer changes. The aims of the study were as follows: (i) to compare the enzymatic activity of eight hydrolytic enzymes and a proportion of microorganism groups during composting and vermicomposting of sewage sludge mixed with straw pellets, (ii) to find the impact of precomposting on enzymatic activity, microorganisms, and earthworm presence, (iii) to determine the effect of addition of straw pellets on the above-mentioned biological properties.

\section{MATERIALS AND METHODS}

\section{Feedstocks}

Sewage sludge was obtained from a sewage treatment plant located in a small town in the Czechia. The sludge did not undergo any stabilization process. The dry matter content was $13.3 \%$, and the total content of $\mathrm{C}, \mathrm{N}, \mathrm{P}, \mathrm{K}, \mathrm{Ca}$, and $\mathrm{Mg}$ was $32.9,5.3,1.6,0.5,1.4$, and $0.5 \%$ in dry matter, respectively. The $\mathrm{pH} / \mathrm{H}_{2} \mathrm{O}(1: 5, \mathrm{w} / \mathrm{v})$ value was 7.0. The content of pollutants $\mathrm{did}$ not exceed the valid legislation. Pelletized straw pellets (PWS) were bought at the Granofyt Ltd., company. The pellet diameter was $10 \mathrm{~mm}$. Because of very reduced pellet moisture, they were mixed with hot water $\left(60^{\circ} \mathrm{C}\right)$ at the rate of $1: 4(\mathrm{w} / \mathrm{v})$ before experimental use. The pellets were added to the sludge to plump the structure with enough air and an increased $\mathrm{C}: \mathrm{N}$ ratio (53.2). The total content of C, N, P, K, Ca, and Mg was 42.6, 0.8, 0.1, 0.6, 0.4 , and $0.1 \%$ in dry matter, respectively. The enzymatic activity and content of the main microorganism groups in feedstocks are shown in Table 1.

\section{Experimental Design Composting}

For composting, five treatments were established:

(1) sludge $100 \%$

(2) sludge $75 \%+$ PWS $25 \%$

(3) sludge $50 \%+$ PWS $50 \%$

(4) sludge $25 \%+$ PWS $75 \%$

(5) PWS $100 \%$

The feedstocks and its mixtures were thoroughly stirred and then were composted for 4 months in aerobic composters with $70-\mathrm{L}$ working volume and $56-\mathrm{cm}$ diameter. Aeration was provided from the bottom of the composter by a compressor. For the first 14 days (thermophilic phase), the air flow was set at $4 \mathrm{~L} / \mathrm{min}$ for $5 \mathrm{~min}$ every half an hour and then for 3 min every

TABLE 1 | Enzymatic activity and content of microorganisms in input raw materials.

\begin{tabular}{|c|c|c|}
\hline & Sewage sludge & $\begin{array}{c}\text { Peletized } \\
\text { wheat straw }\end{array}$ \\
\hline$\beta$-D-glucosidase ( $\mu \mathrm{mol}$ MUFG/h/g dw) & $679 \pm 78$ & $22 \pm 3$ \\
\hline Acid phosphatase ( $\mu \mathrm{mol}$ MUFP/h/g dw) & $4,411 \pm 690$ & $80 \pm 3$ \\
\hline Arylsulphatase ( $\mu \mathrm{mol}$ MUFS/h/g dw) & $173 \pm 32$ & $4 \pm 0$ \\
\hline Lipase ( $\mu$ mol MUFY/h/g dw) & $9,020 \pm 131$ & $283 \pm 31$ \\
\hline Chitinase ( $\mu \mathrm{mol}$ MUFN/h/g dw) & $556 \pm 81$ & $1 \pm 2$ \\
\hline Cellobiohydrolase ( $\mu \mathrm{mol}$ MUFC/h/g dw) & $270 \pm 2$ & $4 \pm 4$ \\
\hline Alanine aminopeptidase ( $\mu \mathrm{mol}$ AMCA/h/g dw) & $1,185 \pm 116$ & $0 \pm 0$ \\
\hline Leucine aminopeptidase ( $\mu \mathrm{mol}$ AMCL/h/g dw) & $880 \pm 67$ & $2 \pm 0$ \\
\hline Fungi ( $\mu \mathrm{g}$ PLFA/g dw) & $146 \pm 2$ & $24 \pm 3$ \\
\hline Bacteria ( $\mu$ g PLFA/g dw) & $3,150 \pm 83$ & $53 \pm 6$ \\
\hline Actinobacteria ( $\mu \mathrm{g}$ PLFA $g$ dw) & $34 \pm 0$ & $1 \pm 0$ \\
\hline $\mathrm{G}+(\mu \mathrm{g}$ PLFA/g dw) & $1,159 \pm 34$ & $20 \pm 3$ \\
\hline$G-(\mu g$ PLFA $g \mathrm{dw})$ & $1,766 \pm 47$ & $22 \pm 4$ \\
\hline Total microbial biomass ( $\mu \mathrm{g}$ PLFA/g dw) & $4,145 \pm 93$ & $122 \pm 9$ \\
\hline
\end{tabular}

Values are means $\pm S D(n=3)$.

$d w$, dry weight; MUFG, 4-methylumbellyferyl- $\beta$ - $D$-glucopyranoside; MUFP, 4-methylumbellyferyl-phosphate; MUFS, 4-methylumbellyferyl sulfate potassium salt; MUFY, 4-methylumbellyferyl-caprylate; MUFN, 4-methylumbellyferyl-N-acetylglucosaminide; MUFC, 4-methylumbellyferyl$N$-cellobiopyranoside; AMCA, L-alanine-7-amido-4-methylcoumarin; AMCL, L-leucine-7-amido-4-methylcoumarin; PLFA, phospholipid fatty acids. 
half an hour. A temperature probe was inserted from the top of the composter to reach half the material height. The temperature was recorded every hour, and the values were collected in a data logger. Prior to sampling at the end of each month, any leachate was poured back into the composted material to achieve a closed loop of substances, and then the composted material was mixed thoroughly to achieve maximum homogeneity. Six samples $(n=6)$ of $0.5 \mathrm{~kg}$ each were taken.

\section{Vermicomposting of Fresh and Precomposted Feedstock}

For vermicomposting, five treatments were established as in the case of composting. Each treatment was carried out in triplicate without (as a control) and with earthworms as follows:

(1) sludge $100 \%$ without earthworms.

(2) sludge $100 \%$ with earthworms.

(3) sludge 75\% + PWS 25\% without earthworms.

(4) sludge 75\% + PWS 25\% with earthworms.

(5) sludge 50\% + PWS 50\% without earthworms.

(6) sludge $50 \%+$ PWS $50 \%$ with earthworms.

(7) sludge $25 \%+$ PWS $75 \%$ without earthworms.

(8) sludge $25 \%+$ PWS $75 \%$ with earthworms.

(9) PWS 100\% without earthworms.

(10) PWS 100\% with earthworms.

Fresh feedstocks were used in one set and precomposted feedstocks in the second set. Precomposting was conducted in composters, as described above, for 14 days. Vermicomposting trays measuring $40 \times 40 \times 15 \mathrm{~cm}$ were used for this part of the experiment. For vermicomposting with earthworms, 2/3 of the trays were filled with fresh or precomposted feedstocks $(9 \mathrm{~kg})$ and $1 / 3$ with earthworm substrate based on grape marc $(3 \mathrm{~L})$. The bulk density of this fresh substrate was $685 \mathrm{~g} / \mathrm{L}$. The average earthworm density in the substrate was 125 pieces/L, with an average weight of $0.2 \mathrm{~g}$ per piece. The materials were separated by a mesh with $6-\mathrm{mm}$ hole diameter. The earthworm substrate was utilized from the side to allow earthworms to move freely between materials in case of unsuitable conditions in the tested feedstocks, especially in case of ammonia formation in sewage sludge, which is toxic to earthworms. To ensure homogeneity, subsamples were taken from five sites in the tray (near the corners and in the middle). The material in the tray could not be mixed before sampling, as there would be a risk of death of the earthworms present. The total sample weight taken up at the end of each month was $0.5 \mathrm{~kg}$ from each of the three trays $(n=3)$.

\section{Sample Analyses}

With respect to vermicomposting samples, earthworms were taken, counted, washed, and weighed. The cocoon number was also determined. To determine the enzymatic activity and the presence of microorganism groups, $150 \mathrm{~g}$ of the sample was frozen at $-25^{\circ} \mathrm{C}$, which was subsequently lyophilized.

For hydrolytic enzyme determination, a suspension was prepared by homogenizing $0.2 \pm 0.002 \mathrm{~g}$ of a lyophilized compost or vermicompost sample and $20 \mathrm{ml}$ of acetate buffer $(\mathrm{pH}=5)$ at a concentration of $50 \mathrm{mmol} \mathrm{L}^{-1}$ for approximately $30 \mathrm{~s}$ using an Ultra-Turrax instrument (IKA
Labortechnik, Germany). Then, $200 \mu \mathrm{l}$ of the homogenized suspension was pipetted into a microtiter plate, and then the appropriate substrate at the given concentration (c) was added depending on the enzyme $[\beta$-D-glucosidase: 4 -methylumbellyferyl- $\beta$-D-glucopyranoside (MUFG) at $c=2.75 \mathrm{mmol} / \mathrm{L}$, acid phosphatase: 4-methylumbellyferylphosphate (MUFP) at $c=2.75 \mathrm{mmol} / \mathrm{L}$, arylsulphatase: 4-methylumbellyferyl sulfate potassium salt (MUFS) at $c=2.50 \mathrm{mmol} / \mathrm{L}$, lipase: 4-methylumbellyferyl-caprylate (MUFY) at $c=2.50 \mathrm{mmol} / \mathrm{L}$, chitinase: 4-methylumbellyferyl$\mathrm{N}$-acetylglucosaminide (MUFN) at $c=1.00 \mathrm{mmol} / \mathrm{L}$, cellobiohydrolase: 4-methylumbellyferyl-N-cellobiopyranoside (MUFC) at $c=2.50 \mathrm{mmol} / \mathrm{L}$, alanine aminopeptidase: L-alanine7-amido-4-methylcoumarin (AMCA) at $c=2.50 \mathrm{mmol} / \mathrm{L}$, leucine aminopeptidase: L-leucine-7-amido-4-methylcoumarin (AMCL) at $c=2.50 \mathrm{mmol} / \mathrm{L}]$. The microtiter plates were then placed in an incubator heated to $40^{\circ} \mathrm{C}$ for $5 \mathrm{~min}$. Afterward, the substrate fluorescence was measured using a Tecan Infinite ${ }^{\circledR}$ M200 (Tecan, Austria). Subsequently, the plates were again placed into an incubator for $2 \mathrm{~h}$, and the fluorescence was measured again. From the difference between the initial and final value, the enzymatic activity was calculated and is usually given in micromoles of the respective substrate per hour and per gram of sample (Baldrian, 2009; Štursová and Baldrian, 2011). Fluorescence determination using a multifunctional modular reader is fast, modern, and an economically advantageous method for determining the enzymatic activity in a large sample number.

Samples for phospholipid fatty acid (PLFA) determination were extracted using phosphate buffer, chloroform, and methanol (0.8:1:2; v/v/v). Gas chromatography-mass spectrometry (450GC, 240-MS Varian, Walnut Creek, CA, United States) was employed for determination of fatty acid methylated esters. The details of the analyses are described in Hanc et al. (2021).

A CHNS Vario MACRO cube analyzer (Elementar Analysensysteme $\mathrm{GmbH}$, Germany) was used to determine total carbon and nitrogen via a thermal conductivity detector according to Hanc et al. (2017). The total contents of P, K, $\mathrm{Ca}$, and $\mathrm{Mg}$ were determined by decomposition obtained by pressurized wet-ashing $\left(\mathrm{HNO}_{3}+\mathrm{H}_{2} \mathrm{O}_{2}\right)$ of dried samples in a closed system of Ethos 1 (MLS GmbH, Germany). Afterward, the element content was determined using ICP-OES (Agilent 720, Agilent Technologies Inc., United States) according to García-Sánchez et al. (2017).

\section{Statistical Analysis}

Values are arithmetic means of three to six values (according to treatment) \pm standard deviations. Based on the results of normality and homogeneity tests, the non-parametric KruskalWallis test $(P \leq 0.05)$ was chosen for statistical analyses.

\section{RESULTS}

\section{Composting}

After the first month of composting $100 \%$ sludge, there was a sharp $64 \%$ decrease in the enzymatic activity of the eight monitored enzymes. The smallest decrease by $16 \%$ was recorded 


\section{Composting}
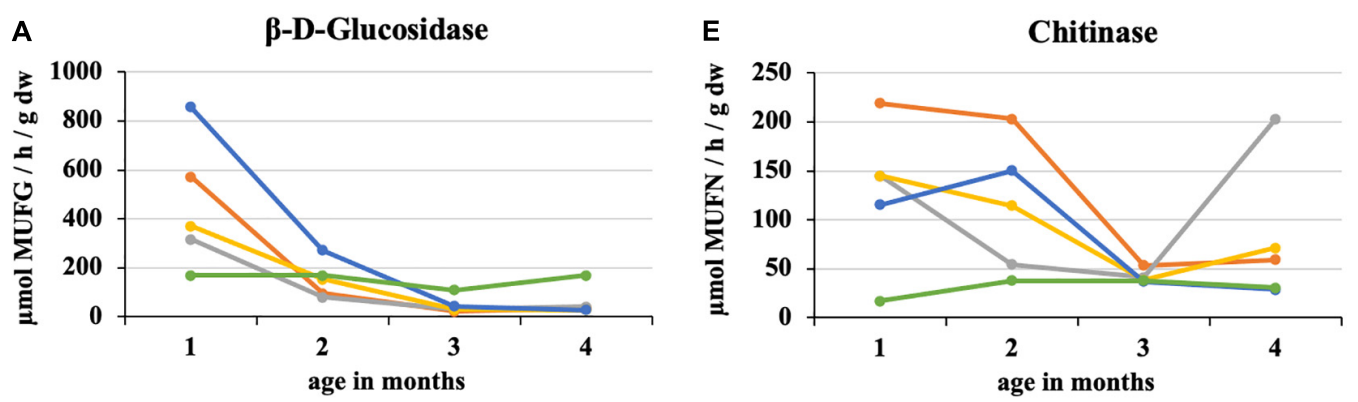

B

Acid phosphatase

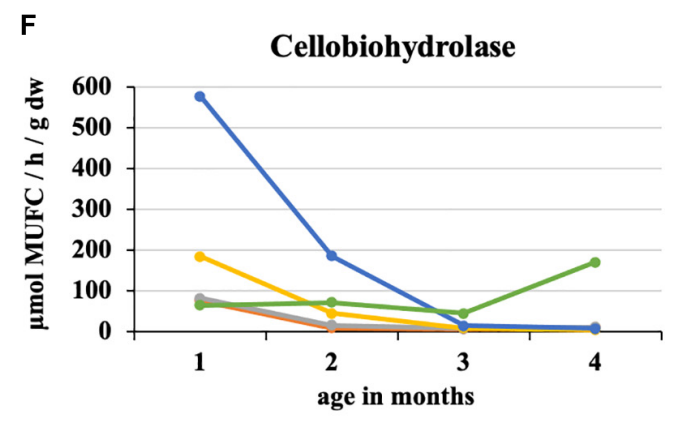

C

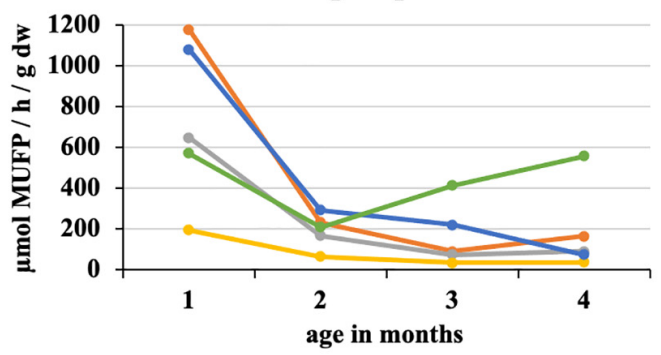

G

Arylsulphatasease
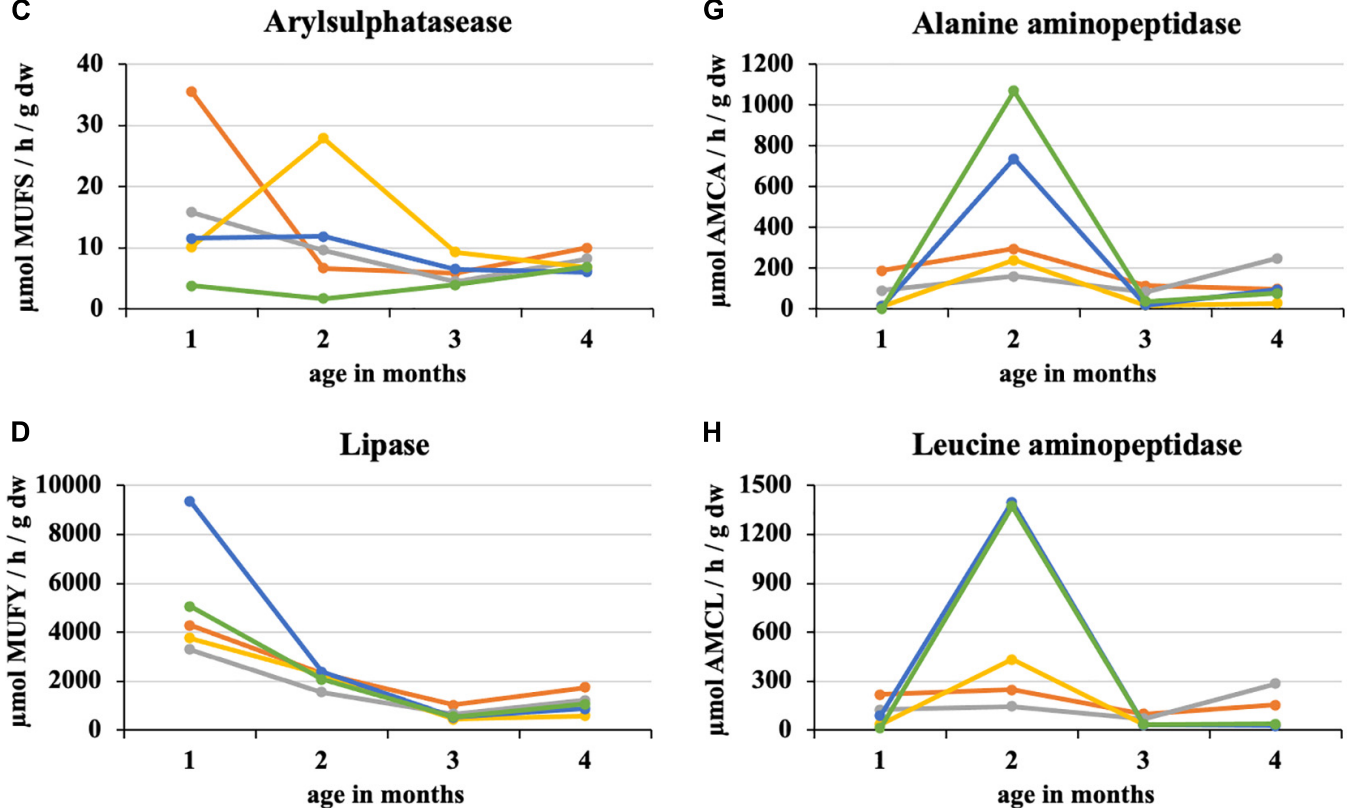

FIGURE 1 | Course of enzymatic activity during composting of fresh feedstock. $=-$, sludge $100 \%$; - , sludge $75 \%$ + PWS 25\%; - - sludge $50 \%$ + PWS 50\%; - sludge 25\% + PWS 75\%, - PWS 100\%; PWS, pelletized wheat straw; dw, dry weight; MUFG, 4-methylumbellyferyl- $\beta$-D-glucopyranoside; MUFP, 4-methylumbellyferyl-phosphate; MUFS, 4-methylumbellyferyl sulfate potassium salt; MUFY, 4-methylumbellyferyl-caprylate; MUFN,

4-methylumbellyferyl-N-acetylglucosaminide; MUFC, 4-methylumbellyferyl-N-cellobiopyranoside; AMCA, L-alanine-7-amido-4-methylcoumarin; AMCL,

L-leucine-7-amido-4-methylcoumarin.

for $\beta$-D-glucosidase, and the greatest by $84 \%$ was for alanine aminopeptidase. The least enzymatic activity at the composting end was recorded for $50 \%$ sludge (acid phosphatase, lipase, cellobiohydrolase, and alanine aminopeptidase) and 25\% straw addition ( $\beta$-D-glucosidase, arylsulphatase, chitinase, and leucin aminopeptidase) as illustrated in Figure 1. Conversely, the 100\% straw was the least mature because of still ongoing decomposition characterized by a great activity of $\beta$-D-glucosidase, acid phosphatase, and cellobiohydrolase. Similarly, arylsulphatase and lipase increased in the second half of the composting period in the case of $100 \%$ sludge. The greatest enzymatic activity was recorded in the first month of composting, except for alanine and leucine 


\section{Composting}
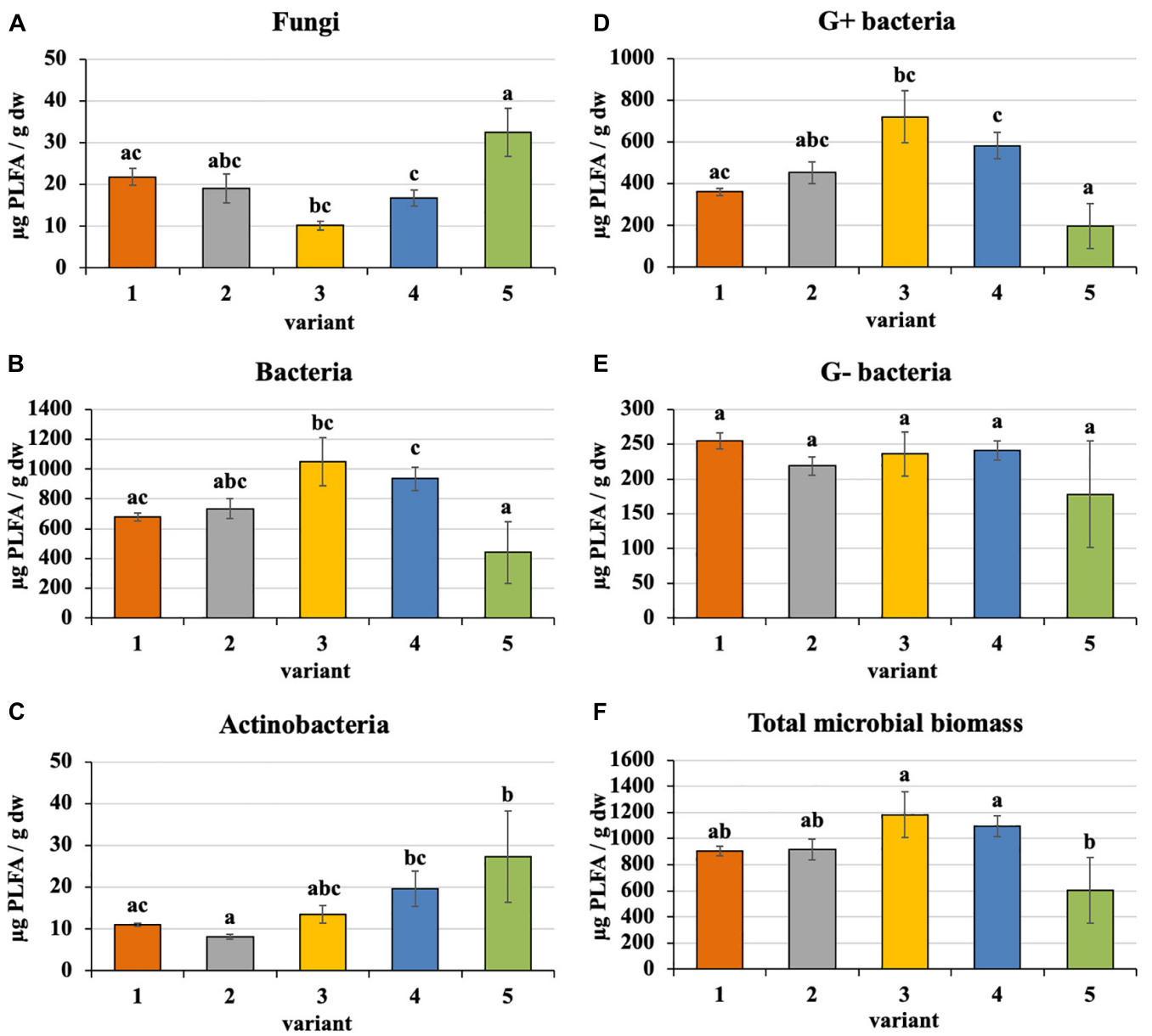

F

Total microbial biomass

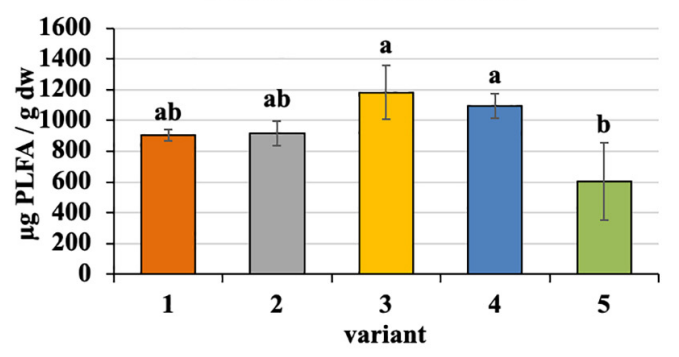

FIGURE 2 | Content of microorganisms after composting feedstock. Treatments: (1) sludge 100\%, (2) sludge 75\% + PWS 25\%, (3) sludge 50\% + PWS 50\%, (4) sludge 25\% + PWS 75\%, and (5) PWS 100\%. Values are means \pm SD ( $n=3)$. Different letters indicate significant differences among treatments (Kruskal-Wallis test, $P \leq 0.05)$. PWS, pelletized wheat straw; PLFA, phospholipid fatty acids; dw, dry weight.

aminopeptidase, which had their distinct peaks in the second month, especially in PWS 100\% and sludge 25\% + PWS 75\%. For most enzymes, a statistically significant difference was found between the first and second halves of the composting process. The statistical differences among the treatments varied according to the individual enzymes and on a time course basis.

Sewage sludge $100 \%$ differed from PWS 100\% in the content and proportion of microorganism groups expressed by PLFA. During composting of $100 \%$ sewage sludge, total microbial biomass, fungi, bacteria, actinobacteria, and G+ and G- bacteria decreased and accounted for 22, 15, 22, 32, 31, and 14\% of used feedstock, respectively. Conversely, microorganism content increased in PWS 100\% at the end with respect to total microbial biomass, fungi, bacteria, actinobacteria, and G+ and G- bacteria by 4. 9-, 1. 4-, 8. 3-, 27. 3-, 9. 8-, and 9.1-fold, respectively. In spite of that, total microbial biomass, bacteria, and G+ and Gbacteria were found to a greater extent in sewage sludge $100 \%$ than in PWS $100 \%$ after 4 months of composting. Conversely, fungi and actinobacteria were greater in PWS 100\% (Figure 2).
The most bacteria and, conversely, the least fungi were found in sludge $50 \%+$ PWS 50\%, followed by sludge 25\% + PWS $75 \%$.

\section{Vermicomposting of Fresh and Precomposted Feedstock}

\section{Enzymes}

During the first month of $100 \%$ fresh sewage sludge vermicomposting, there was a $65 \%$ decrease in the enzymatic activity of eight enzymes (Tables 2,3 ). The enzymatic activity of alanine aminopeptidase decreased the most among enzymes during this period (by $87 \%$ ). In contrast, acid phosphatase activity decreased by only $9 \%$. The average activity of all monitored enzymes decreased in this variant by $95 \%$ after 4 months of vermicomposting. After 1 month of vermicomposting, no difference was found between the treatment with earthworms and without earthworms. However, after the $2^{\text {nd }}$ and $3^{\text {rd }}$ months, the enzymatic activity was greater in treatments with earthworms by 51 and 32\%, respectively. After this time, no differences 
TABLE 2 | Activities of $\beta$-D-glucosidase, acid phosphatase, arylsulphatase, and lipase during vermicomposting fresh feedstock.

\begin{tabular}{|c|c|c|c|c|c|c|c|c|c|c|}
\hline & $\begin{array}{c}\text { Sludge } 100 \% \\
\text { without e. }\end{array}$ & $\begin{array}{l}\text { Sludge } 100 \% \\
\text { with e. }\end{array}$ & $\begin{array}{c}\text { Sludge } \\
75 \%+\text { PWS } 25 \% \\
\text { without e. }\end{array}$ & $\begin{array}{l}\text { Sludge } \\
75 \% \text { + PWS } 25 \% \\
\text { with e. }\end{array}$ & $\begin{array}{c}\text { Sludge } \\
50 \%+\text { PWS } 50 \% \\
\text { without e. }\end{array}$ & 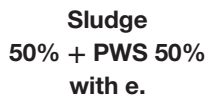 & $\begin{array}{c}\text { Sludge } \\
25 \% \text { + PWS } 75 \% \\
\text { without e. }\end{array}$ & $\begin{array}{l}\text { Sludge } \\
25 \% \text { + PWS } 75 \% \\
\text { with e. }\end{array}$ & $\begin{array}{l}\text { PWS } 100 \% \\
\text { without e. }\end{array}$ & $\begin{array}{c}\text { PWS } 100 \% \text { with } \\
\text { e. }\end{array}$ \\
\hline \multicolumn{11}{|c|}{$\beta$-D-glucosidase $(\mu \mathrm{mol}$ MUFG/h/g dw) } \\
\hline 1 month & $341 \pm 94 \mathrm{aAB}$ & $248 \pm 17 \mathrm{aAB}$ & $914 \pm 196 \mathrm{aA}$ & $250 \pm 71 \mathrm{aAB}$ & $139 \pm 11 \mathrm{aAB}$ & $59 \pm 26 \mathrm{aB}$ & $644 \pm 202 \mathrm{aAB}$ & $779 \pm 303 \mathrm{aA}$ & $118 \pm 54 \mathrm{aAB}$ & $215 \pm 34 \mathrm{aAB}$ \\
\hline 2 months & $26 \pm 1 \mathrm{abA}$ & $25 \pm 4 \mathrm{abA}$ & $50 \pm 4 \mathrm{aAB}$ & $36 \pm 12 \mathrm{abAB}$ & $140 \pm 52 \mathrm{aB}$ & $44 \pm 3 \mathrm{aAB}$ & $60 \pm 16 \mathrm{abAB}$ & $38 \pm 3 \mathrm{abAB}$ & $35 \pm 11 \mathrm{bAB}$ & $57 \pm 14 \mathrm{abAB}$ \\
\hline 3 months & $34 \pm 8 \mathrm{abAB}$ & $14 \pm 8 \mathrm{bAB}$ & $51 \pm 13 \mathrm{aAB}$ & $31 \pm 12 \mathrm{abAB}$ & $47 \pm 16 \mathrm{aAB}$ & $4 \pm 1 \mathrm{aA}$ & $39 \pm 12 \mathrm{bAB}$ & $18 \pm 8 \mathrm{bAB}$ & $61 \pm 19 \mathrm{abB}$ & $27 \pm 4 \mathrm{bAB}$ \\
\hline 4 months & $24 \pm 5 \mathrm{bA}$ & $26 \pm 8 \mathrm{abA}$ & $40 \pm 24 \mathrm{aA}$ & $18 \pm 8 \mathrm{bA}$ & $51 \pm 18 \mathrm{aA}$ & $5 \pm 1 \mathrm{aA}$ & $41 \pm 14 \mathrm{abA}$ & $29 \pm 5 a b A$ & $56 \pm 1 \mathrm{abA}$ & $57 \pm 27 \mathrm{abA}$ \\
\hline \multicolumn{11}{|c|}{ Acid phosphatase ( $\mu \mathrm{mol}$ MUFP/h/g dw) } \\
\hline 1 month & $\begin{array}{c}1,734 \pm 289 \\
a A B\end{array}$ & $\begin{array}{c}4,045 \pm 1,107 \\
\mathrm{aAB}\end{array}$ & $3,111 \pm 701 \mathrm{aAB}$ & $1,867 \pm 628 \mathrm{aAB}$ & $1,413 \pm 520 \mathrm{aAB}$ & $899 \pm 208$ aB & $3,690 \pm 1,403 \mathrm{aAB}$ & $7,065 \pm 2,047 \mathrm{aA}$ & $970 \pm 293 \mathrm{aB}$ & $1,295 \pm 342 \mathrm{aAB}$ \\
\hline 2 months & $280 \pm 56 \mathrm{bA}$ & $368 \pm 146 \mathrm{abA}$ & $1,859 \pm 86 \mathrm{abB}$ & $517 \pm 65 \mathrm{abAB}$ & $1,319 \pm 312 \mathrm{aAB}$ & $458 \pm 41 \mathrm{abAB}$ & $749 \pm 207 \mathrm{abAB}$ & $551 \pm 83 \mathrm{aAB}$ & $893 \pm 218 \mathrm{aAB}$ & $729 \pm 190 \mathrm{abAB}$ \\
\hline 3 months & $\begin{array}{c}385 \pm 121 \\
a b A B\end{array}$ & $212 \pm 41 \mathrm{bAB}$ & $378 \pm 108 \mathrm{abAB}$ & $90 \pm 19 \mathrm{bA}$ & $613 \pm 152 \mathrm{aB}$ & $372 \pm 103 \mathrm{abAB}$ & $421 \pm 37 \mathrm{bAB}$ & $275 \pm 96 \mathrm{aAB}$ & $235 \pm 87 \mathrm{aAB}$ & $457 \pm 112 \mathrm{abAB}$ \\
\hline 4 months & $423 \pm 177 \mathrm{abA}$ & $243 \pm 15 a b A$ & $331 \pm 112 \mathrm{bA}$ & $209 \pm 50 a b A$ & $572 \pm 237 \mathrm{aA}$ & $317 \pm 136 \mathrm{bA}$ & $516 \pm 42 \mathrm{abA}$ & $254 \pm 57$ aA & $280 \pm 30 \mathrm{aA}$ & $269 \pm 84 \mathrm{bA}$ \\
\hline \multicolumn{11}{|c|}{ Arylsulphatase $(\mu \mathrm{mol}$ MUFS $/ \mathrm{h} / \mathrm{g} \mathrm{dw})$} \\
\hline 1 month & $31 \pm 5 \mathrm{aA}$ & $31 \pm 3 a A$ & $27 \pm 12 \mathrm{aAB}$ & $19 \pm 9 \mathrm{aAB}$ & $5 \pm 2 \mathrm{aAB}$ & $0 \pm 0 \mathrm{aB}$ & $13 \pm 0 \mathrm{aAB}$ & $12 \pm 6 \mathrm{aAB}$ & $10 \pm 0 \mathrm{aAB}$ & $9 \pm 0 \mathrm{aAB}$ \\
\hline 2 months & $3 \pm 0 \mathrm{abAB}$ & $4 \pm 0 \mathrm{bA}$ & $3 \pm 1 \mathrm{aAB}$ & $3 \pm 2 \mathrm{abAB}$ & $0 \pm 0 \mathrm{bB}$ & $0 \pm 0 \mathrm{aB}$ & $2 \pm 1 \mathrm{bAB}$ & $1 \pm 1 \mathrm{abAB}$ & $4 \pm 0 \mathrm{bAB}$ & $3 \pm 1 \mathrm{bAB}$ \\
\hline 3 months & $1 \pm 0 \mathrm{bAB}$ & $5 \pm 2 \mathrm{abAB}$ & $4 \pm 3 \mathrm{aAB}$ & $4 \pm 2 \mathrm{abAB}$ & $3 \pm 1 \mathrm{abAB}$ & $5 \pm 2 \mathrm{aAB}$ & $4 \pm 3 a b A B$ & $0 \pm 0 \mathrm{bA}$ & $7 \pm 2 \mathrm{abB}$ & $4 \pm 1 \mathrm{abAB}$ \\
\hline 4 months & $5 \pm 3 a b A$ & $5 \pm 0 \mathrm{abA}$ & $3 \pm 2 \mathrm{aA}$ & $0 \pm 0 \mathrm{bA}$ & $2 \pm 1 \mathrm{abA}$ & $4 \pm 3 \mathrm{aA}$ & $5 \pm 3 \mathrm{abA}$ & $1 \pm 1 \mathrm{abA}$ & $6 \pm 2 \mathrm{abA}$ & $6 \pm 1 \mathrm{abA}$ \\
\hline \multicolumn{11}{|c|}{ Lipase $(\mu \mathrm{mol}$ MUFY/h/g dw) } \\
\hline 1 month & $\begin{array}{c}3,375 \pm 772 \\
\text { aAB }\end{array}$ & $\begin{array}{c}2,976 \pm 352 \\
\text { aAB }\end{array}$ & $4,153 \pm 1,009 \mathrm{aAB}$ & $2,449 \pm 780 \mathrm{aAB}$ & $5,372 \pm 1,490 \mathrm{aB}$ & $3,262 \pm 268 \mathrm{aAB}$ & $2,837 \pm 624 \mathrm{aAB}$ & $3,115 \pm 763 \mathrm{aAB}$ & $1,333 \pm 375 \mathrm{aA}$ & $1,489 \pm 914 \mathrm{aA}$ \\
\hline 2 months & $\begin{array}{c}748 \pm 113 \\
a b A B\end{array}$ & $648 \pm 345 \mathrm{aAB}$ & $1,436 \pm 275 \mathrm{abA}$ & $422 \pm 118 \mathrm{aB}$ & $1,234 \pm 263 \mathrm{abAB}$ & $830 \pm 203 \mathrm{abAB}$ & $892 \pm 148 \mathrm{abAB}$ & $830 \pm 267 \mathrm{abAB}$ & $360 \pm 155 \mathrm{aB}$ & $914 \pm 197 \mathrm{aAB}$ \\
\hline 3 months & $396 \pm 72 \mathrm{bA}$ & $477 \pm 53 \mathrm{aA}$ & $615 \pm 160 \mathrm{abA}$ & $582 \pm 498 \mathrm{aA}$ & $405 \pm 8 \mathrm{bA}$ & $527 \pm 250 \mathrm{abA}$ & $325 \pm 181 \mathrm{bA}$ & $213 \pm 93 \mathrm{bA}$ & $404 \pm 206 a A$ & $440 \pm 153 \mathrm{aA}$ \\
\hline 4 months & $716 \pm 197 \mathrm{abA}$ & $515 \pm 289 \mathrm{aA}$ & $490 \pm 189 \mathrm{bA}$ & $382 \pm 52 \mathrm{aA}$ & $452 \pm 128 \mathrm{abA}$ & $371 \pm 28 \mathrm{bA}$ & $439 \pm 110 \mathrm{abA}$ & $386 \pm 182 a b A$ & $426 \pm 107 \mathrm{aA}$ & $445 \pm 92 \mathrm{aA}$ \\
\hline
\end{tabular}

Values are means $\pm S D(n=3)$. Different lowercase letters in a column indicate significant differences between months, while capital letters indicate significant differences among treatments (Kruskal-Wallis test, $P \leq 0.05$ ).

dW, dry weight; PWS, pelletized wheat straw; e., earthworms; MUFG, 4-methylumbellyferyl- $\beta$-D-glucopyranoside; MUFP, 4-methylumbellyferyl-phosphate; MUFS, 4-methylumbellyferyl sulfate potassium salt; MUFY, 4-methylumbellyferyl-caprylate. 
TABLE 3 | Activities of chitinase, cellobiohydrolase, alanine aminopeptidase, and leucine aminopeptidase during vermicomposting fresh feedstock.

\begin{tabular}{|c|c|c|c|c|c|c|c|c|c|c|}
\hline & $\begin{array}{c}\text { Sludge } 100 \% \\
\text { without e. }\end{array}$ & $\begin{array}{l}\text { Sludge } 100 \% \\
\text { with e. }\end{array}$ & $\begin{array}{c}\text { Sludge } \\
75 \% \text { + PWS } 25 \% \\
\text { without e. }\end{array}$ & $\begin{array}{c}\text { Sludge } \\
75 \% \text { + PWS } 25 \% \\
\text { with e. }\end{array}$ & $\begin{array}{c}\text { Sludge } \\
50 \%+\text { PWS } 50 \% \\
\text { without e. }\end{array}$ & $\begin{array}{c}\text { Sludge } \\
50 \%+\text { PWS } 50 \% \\
\text { with e. }\end{array}$ & $\begin{array}{c}\text { Sludge } \\
25 \% \text { + PWS } 75 \% \\
\text { without e. }\end{array}$ & $\begin{array}{l}\text { Sludge } \\
25 \% \text { + PWS } 75 \% \\
\text { with e. }\end{array}$ & $\begin{array}{l}\text { PWS } 100 \% \\
\text { without e. }\end{array}$ & $\begin{array}{c}\text { PWS } 100 \% \text { with } \\
\text { e. }\end{array}$ \\
\hline \multicolumn{11}{|c|}{ Chitinase $(\mu \mathrm{mol}$ MUFN/h/g dw) } \\
\hline 1 month & $525 \pm 90 \mathrm{aA}$ & $329 \pm 7$ aAB & $391 \pm 131 \mathrm{aAB}$ & $191 \pm 21 \mathrm{aAB}$ & $243 \pm 59$ aAB & $380 \pm 64$ aAB & $297 \pm 121 \mathrm{aAB}$ & $183 \pm 30 \mathrm{aAB}$ & $59 \pm 11 \mathrm{aB}$ & $57 \pm 30 \mathrm{aB}$ \\
\hline 2 months & $42 \pm 22 \mathrm{abAB}$ & $20 \pm 12 \mathrm{aAB}$ & $42 \pm 8 \mathrm{abAB}$ & $15 \pm 7 \mathrm{abA}$ & $125 \pm 30 \mathrm{abB}$ & $50 \pm 4 \mathrm{abAB}$ & $83 \pm 30 \mathrm{abAB}$ & $43 \pm 8 \mathrm{abAB}$ & $17 \pm 4 \mathrm{bAB}$ & $39 \pm 17 \mathrm{aAB}$ \\
\hline 3 months & $29 \pm 10 \mathrm{bAB}$ & $26 \pm 10 \mathrm{aAB}$ & $27 \pm 7 \mathrm{abAB}$ & $22 \pm 10 \mathrm{abAB}$ & $41 \pm 1 \mathrm{abA}$ & $20 \pm 6 b A B$ & $35 \pm 16 \mathrm{bAB}$ & $11 \pm 5 \mathrm{abB}$ & $33 \pm 15 \mathrm{abAB}$ & $34 \pm 3 \mathrm{aAB}$ \\
\hline 4 months & $60 \pm 21 \mathrm{abA}$ & $20 \pm 6$ aAB & $23 \pm 4 \mathrm{bAB}$ & $13 \pm 1 \mathrm{bAB}$ & $33 \pm 4 \mathrm{bAB}$ & $29 \pm 9 \mathrm{abAB}$ & $42 \pm 19 \mathrm{abAB}$ & $10 \pm 0 \mathrm{bB}$ & $30 \pm 15 \mathrm{abAB}$ & $47 \pm 9 \mathrm{aAB}$ \\
\hline \multicolumn{11}{|c|}{ Cellobiohydrolase ( $\mu \mathrm{mol}$ MUFC/h/g dw) } \\
\hline 1 month & $57 \pm 21 \mathrm{aA}$ & $40 \pm 6 \mathrm{aA}$ & $311 \pm 46 \mathrm{aA}$ & $63 \pm 21 \mathrm{aA}$ & $111 \pm 29 \mathrm{aA}$ & $134 \pm 22 \mathrm{aA}$ & $300 \pm 168 \mathrm{aA}$ & $326 \pm 1 \mathrm{aA}$ & $38 \pm 22 \mathrm{aA}$ & $106 \pm 26 \mathrm{aA}$ \\
\hline 2 months & $9 \pm 5 \mathrm{abA}$ & $7 \pm 5$ aA & $13 \pm 5 \mathrm{abA}$ & $7 \pm 3 a b A$ & $16 \pm 7 \mathrm{abA}$ & $11 \pm 0 \mathrm{abA}$ & $23 \pm 6 \mathrm{abA}$ & $9 \pm 6 \mathrm{abA}$ & $16 \pm 2 \mathrm{abA}$ & $12 \pm 0 \mathrm{aA}$ \\
\hline 3 months & $4 \pm 3 \mathrm{bA}$ & $15 \pm 9$ aA & $7 \pm 3 \mathrm{abA}$ & $10 \pm 6 \mathrm{abA}$ & $12 \pm 3 \mathrm{abA}$ & $5 \pm 2 \mathrm{abA}$ & $9 \pm 4 \mathrm{bA}$ & $3 \pm 2 \mathrm{bA}$ & $12 \pm 2 \mathrm{bA}$ & $10 \pm 2 \mathrm{aA}$ \\
\hline 4 months & $6 \pm 3 a b A B$ & $6 \pm 2 \mathrm{aAB}$ & $6 \pm 2 \mathrm{bAB}$ & $3 \pm 1 \mathrm{bA}$ & $6 \pm 1 \mathrm{bAB}$ & $4 \pm 3 \mathrm{bAB}$ & $12 \pm 5 \mathrm{abAB}$ & $6 \pm 3 \mathrm{abAB}$ & $35 \pm 3 \mathrm{abB}$ & $10 \pm 5 \mathrm{aAB}$ \\
\hline \multicolumn{11}{|c|}{ Alanine aminopeptidase $(\mu \mathrm{mol}$ AMCA $/ \mathrm{h} / \mathrm{g} \mathrm{dw})$} \\
\hline 1 month & $98 \pm 2 \mathrm{aAB}$ & $151 \pm 43 \mathrm{aA}$ & $143 \pm 57 \mathrm{aAB}$ & $88 \pm 21 \mathrm{aAB}$ & $27 \pm 7 \mathrm{aB}$ & $32 \pm 4 \mathrm{aAB}$ & $81 \pm 10 \mathrm{aAB}$ & $89 \pm 37 \mathrm{aAB}$ & $44 \pm 1 \mathrm{aAB}$ & $28 \pm 3 \mathrm{aB}$ \\
\hline 2 months & $34 \pm 2 \mathrm{aAB}$ & $28 \pm 12 \mathrm{aAB}$ & $58 \pm 11 \mathrm{abAB}$ & $33 \pm 14 \mathrm{abAB}$ & $42 \pm 9 \mathrm{aAB}$ & $31 \pm 1 \mathrm{abA}$ & $78 \pm 4 \mathrm{aAB}$ & $47 \pm 3 \mathrm{abAB}$ & $43 \pm 5 \mathrm{aAB}$ & $82 \pm 4 \mathrm{bB}$ \\
\hline 3 months & $28 \pm 16 \mathrm{aA}$ & $25 \pm 11 \mathrm{aA}$ & $39 \pm 19 \mathrm{abA}$ & $27 \pm 7 \mathrm{abA}$ & $41 \pm 10 \mathrm{aA}$ & $18 \pm 1 \mathrm{abA}$ & $25 \pm 12 \mathrm{aA}$ & $15 \pm 1 \mathrm{abA}$ & $38 \pm 16 \mathrm{aA}$ & $44 \pm 19 \mathrm{abA}$ \\
\hline 4 months & $25 \pm 4$ aAB & $23 \pm 4 \mathrm{aAB}$ & $22 \pm 6 b A B$ & $12 \pm 7 \mathrm{bAB}$ & $10 \pm 7 \mathrm{aAB}$ & $13 \pm 2 \mathrm{bAB}$ & $20 \pm 7 \mathrm{aAB}$ & $5 \pm 1 \mathrm{bA}$ & $46 \pm 2 \mathrm{aB}$ & $45 \pm 3 \mathrm{abB}$ \\
\hline \multicolumn{11}{|c|}{ Leucine aminopeptidase $(\mu \mathrm{mol}$ AMCL/h/g dw) } \\
\hline 1 month & $112 \pm 14 \mathrm{aA}$ & $197 \pm 65 \mathrm{aAB}$ & $147 \pm 45 a$ & $90 \pm 14 \mathrm{aA}$ & $166 \pm 15 \mathrm{aAB}$ & $286 \pm 63$ aAB & $292 \pm 58$ aAB & $419 \pm 97 \mathrm{aB}$ & $194 \pm 59 \mathrm{aAB}$ & $258 \pm 88$ aAB \\
\hline 2 months & $91 \pm 37 \mathrm{abAB}$ & $87 \pm 22 \mathrm{abAB}$ & $66 \pm 37 \mathrm{abAB}$ & $26 \pm 11 \mathrm{abA}$ & $78 \pm 4 \mathrm{abAB}$ & $224 \pm 25 \mathrm{abAB}$ & $210 \pm 60 \mathrm{aAB}$ & $237 \pm 19 \mathrm{abA}$ & $55 \pm 5 \mathrm{abAB}$ & $215 \pm 64 \mathrm{aAB}$ \\
\hline 3 months & $38 \pm 2 \mathrm{bAB}$ & $15 \pm 9 \mathrm{bAB}$ & $23 \pm 2 \mathrm{abAB}$ & $20 \pm 8 \mathrm{abAB}$ & $25 \pm 8 \mathrm{abAB}$ & $85 \pm 37 \mathrm{abAB}$ & $12 \pm 4 \mathrm{aA}$ & $12 \pm 1 \mathrm{abA}$ & $47 \pm 9 \mathrm{abAB}$ & $129 \pm 7 \mathrm{aB}$ \\
\hline 4 months & $43 \pm 5 \mathrm{abAB}$ & $32 \pm 7 \mathrm{abAB}$ & $22 \pm 1 \mathrm{bAB}$ & $9 \pm 2 \mathrm{bA}$ & $9 \pm 4 \mathrm{bA}$ & $21 \pm 9 \mathrm{bAB}$ & $9 \pm 4 \mathrm{aAB}$ & $11 \pm 2 \mathrm{bAB}$ & $44 \pm 7 \mathrm{bAB}$ & $114 \pm 35 \mathrm{aB}$ \\
\hline
\end{tabular}

Values are means $\pm S D(n=3)$. Different lowercase letters in a column indicate significant differences between months, while capital letters indicate significant differences among treatments (Kruskal-Wallis test, $P \leq 0.05)$.

dw, dry weight; PWS, pelletized wheat straw; e. = earthworms; MUFN, 4-methylumbellyferyl-N-acetylglucosaminide; MUFC, 4-methylumbellyferyl-N-cellobiopyranoside; AMCA, L-alanine-7-amido-4-methylcoumarin: AMCL, L-leucine-7-amido-4-methylcoumarin. 


\section{Vermicomposting of precomposted feedstocks}
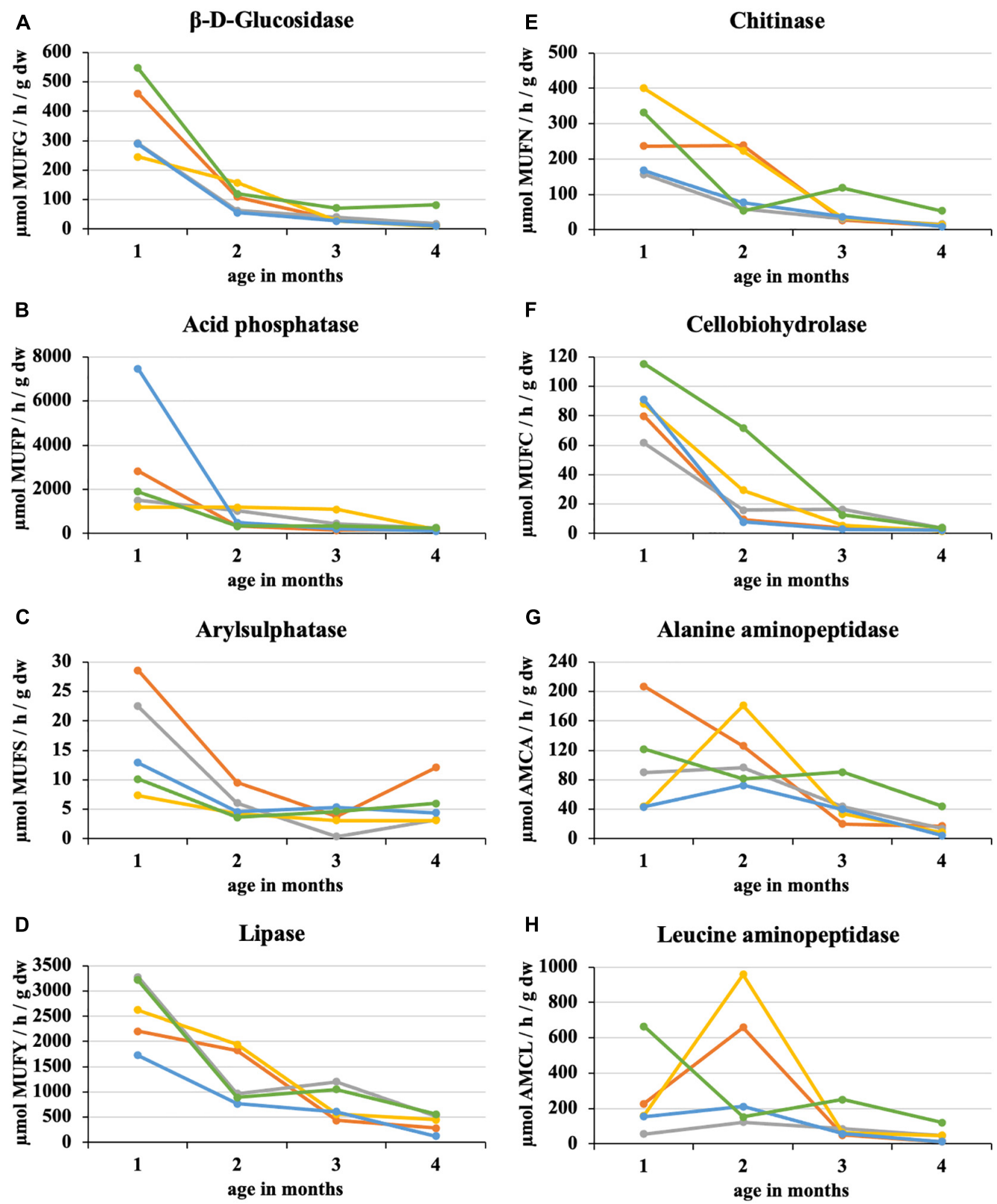

FIGURE 3 | Course of enzymatic activity during vermicomposting of precomposted feedstock. =- sludge 100\% with earthworms; 2 - sludge $75 \%+$ PWS 25\% with earthworms; $=$, sludge 50\% + PWS 50\% with earthworms; =- sludge 25\% + PWS 75\% with earthworms; - - , PWS 100\% with earthworms; PWS, pelletized wheat straw; dw, dry weight; MUFG, 4-methylumbellyferyl- $\beta$-D-glucopyranoside; MUFP, 4-methylumbellyferyl-phosphate; MUFS,

4-methylumbellyferyl sulfate potassium salt; MUFY, 4-methylumbellyferyl-caprylate; MUFN, 4-methylumbellyferyl-N-acetylglucosaminide; MUFC,

4-methylumbellyferyl-N-cellobiopyranoside; AMCA, L-alanine-7-amido-4-methylcoumarin; AMCL, L-leucine-7-amido-4-methylcoumarin.

in average enzymatic activity were apparent. However, the situation was different for individual enzymes. PWS 100\% was characterized by a significantly greater enzymatic activity in the earthworm treatments, especially in the case of $\beta$-D-glucosidase, acid phosphatase, lipase, chitinase, and leucin aminopeptidase. The least enzymatic activity was found at the vermicomposting end in mixtures, especially in sludge $75 \%+$ PWS $25 \%$.
During 2 weeks of precomposting, the enzymatic activity of eight enzymes in $100 \%$ sewage sludge decreased by an average of $45 \%$. A further decrease of $25 \%$ was recorded in the first month of subsequent vermicomposting (Figure 3). At the end of the $1^{\text {st }}$ month of vermicomposting, some enzyme values were greater than at the beginning (i.e., immediately after precomposting). Specifically, these enzymes were PWS (all enzymes), sludge 


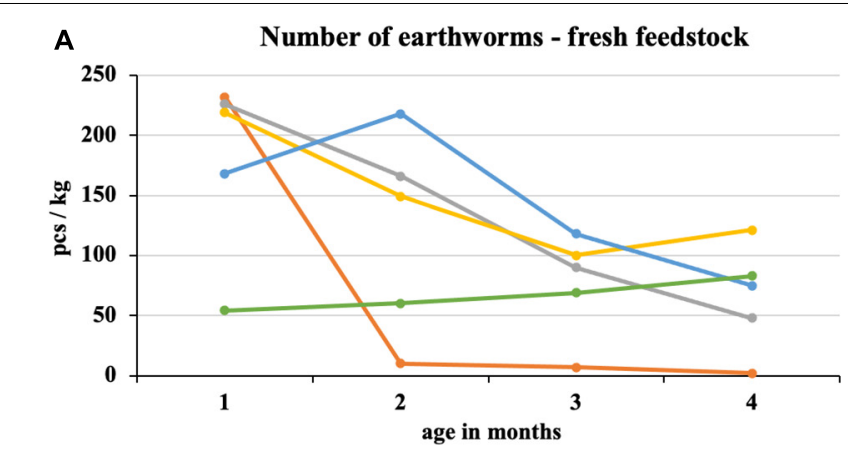

B

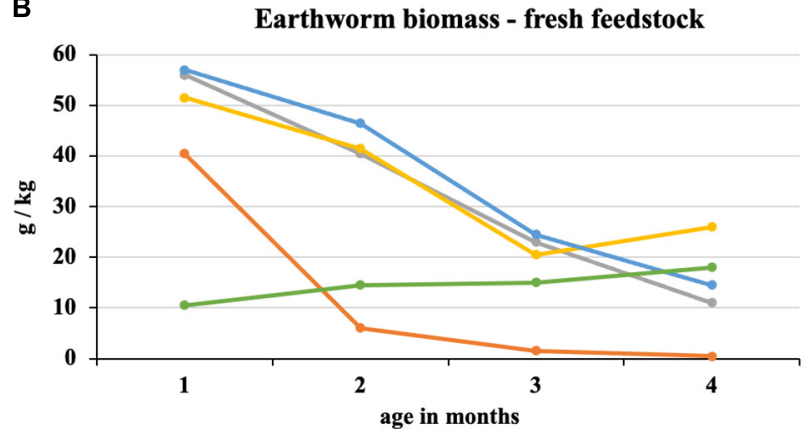

C

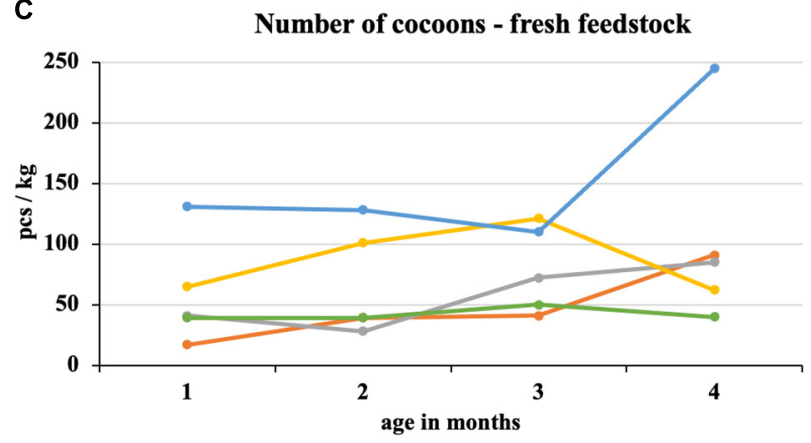

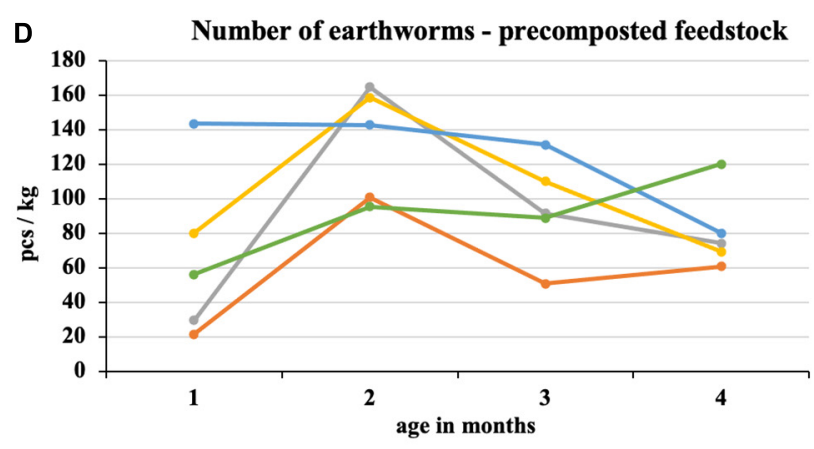

E

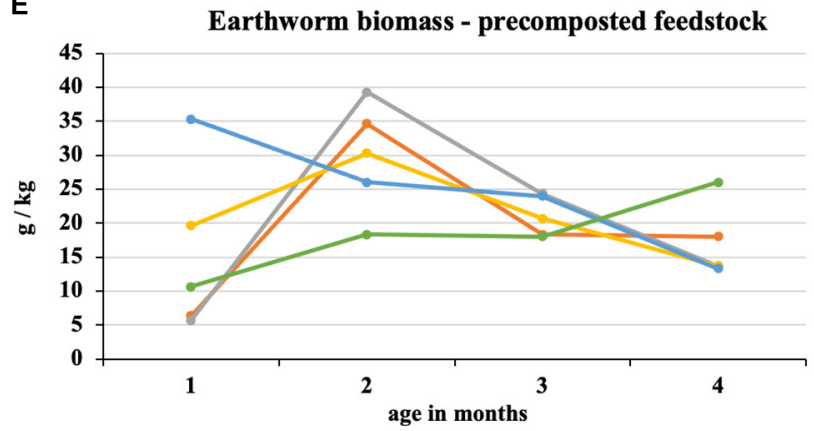

$\mathbf{F}$

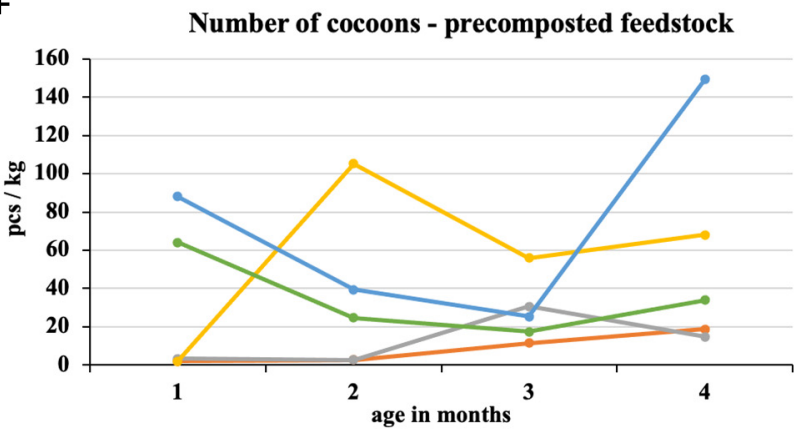

FIGURE 4 | Course of number of earthworms, earthworm biomass, and number of cocoons in treatments with vermicomposting of fresh feedstock (A-C) and with vermicomposting of precomposted feedstock $(\mathbf{D}-\mathbf{F}) .=$, sludge $100 \%$ with earthworms; - - sludge $75 \%+$ PWS $25 \%$ with earthworms; - , sludge 50\% + PWS 50\% with earthworms; $=$, sludge 25\% + PWS 75\% with earthworms; - , PWS 100\% with earthworms; PWS, pelletized wheat straw.

$25 \%+$ PWS 75\% (acid phosphatase, arylsulphatase, chitinase, cellobiohydrolase, alanine aminopeptidase, and leucin aminopeptidase), sludge 50\% + PWS 50\% (acid phosphatase, chitinase, alanine aminopeptidase, and leucin aminopeptidase), sludge $75 \%+$ PWS 25\% (acid phosphatase), and sludge $100 \%$ (acid phosphatase and cellobiohydrolase). Thus, acid phosphatase increased in all treatments. Since the end of the $1^{\text {st }}$ month, enzymatic activity decreased (the same Figure 3). During vermicomposting of precomposted feedstocks, the enzymatic activity decreased. For most enzymes, it was significant after the $1^{\text {st }}$ month. As in the case of composting, alanin and leucin aminopeptidase, in some treatments (e.g., Sludge 50\% + PWS $50 \%$ ), increased after 1 month and decreased later. Of the monitored treatments, the greatest decrease (91\%) was in the sludge $25 \%$ + PWS 75\% treatment, followed by the sludge $100 \%$ treatment (by $89 \%$ ), sludge $50 \%+$ PWS 50\% (by $83 \%$ ), sludge $25 \%+$ PWS 75\% (by 79\%), and PWS 100\% (by 78\%).

\section{Earthworms}

After the first month of fresh feedstock vermicomposting, most earthworms were in $100 \%$ sewage sludge and mixtures with its high proportion (Figure 4). In these treatments, there was a subsequent decrease in earthworm number, which was directly proportional to the sewage sludge proportion. The difference between the process beginning and end was statistically significant in the sewage sludge $100 \%$ and sewage sludge $75 \%+$ PWS 25\%. After the first month, the earthworm number in sludge 25\% + PWS 75\% increased (Figure 4A), but the earthworm biomass decreased (Figure 4B), which was due to the reduced weight of individual earthworm pieces. PWS 100\% showed four times less earthworm number and five times less earthworm biomass than other treatments at the process beginning. During the following months, however, these parameters increased, and this treatment was included among the other mixed treatments. The earthworms decreased significantly 
in $100 \%$ sewage sludge, where only two pieces per kilogram were present at the end of vermicomposting. The cocoon number (Figure 4C) in the vermicomposted material increased during the process (at the beginning, 17-131 pieces/kg; in the end, 40-245 pieces $/ \mathrm{kg}$ ). Sewage sludge $25 \%+$ PWS $75 \%$ was characterized by the greatest number of loaded cocoons.

In the case of precomposted feedstock, the greatest number and earthworm biomass were found in three treatments with the greatest sludge proportion at the end of the $2^{\text {nd }}$ month of vermicomposting (Figures 4D,E). An approximately sixfold increase was found in the $75 \%$ sludge treatment. The earthworm number in the $25 \%$ sludge treatment was the greatest of all tested treatments at the process beginning (143 pieces $/ \mathrm{kg}$ ) and differed statistically from the $100 \%$ sludge treatment. It was the most stable treatment with a slight decrease. Conversely, PWS 100\% showed a continuous increase in earthworm number and biomass. The earthworm number in this treatment varied statistically at the process beginning and in the end and reached the greatest values among all treatments $(120$ pieces $/ \mathrm{kg})$. PWS addition to the sludge and PWS itself caused an increase in the cocoon number in the $1^{\text {st }}$ month and at the process end (Figure 4F). The cocoon number in the $100 \%$ sludge and the $75 \%$ sludge treatments increased slightly in the $2^{\text {nd }}$ half of vermicomposting. Nevertheless, these treatments contained fewer cocoons at the end of vermicomposting compared to treatments with a greater PWS proportion.

\section{Microorganisms}

Similarly, as in the case of composting, fresh sewage sludge $100 \%$ differed from PWS 100\% in the content and proportion of microorganism groups. During vermicomposting of $100 \%$ sewage sludge, total microbial biomass, fungi, bacteria, actinobacteria, and G+ and G- bacteria decreased and accounted for 9, 4, 9, 31, 13, and 5\% of used feedstock, respectively. Conversely, the microorganism content increased in PWS 100\% at the end, including total microbial biomass, fungi, bacteria, actinobacteria, and G+ and Gbacteria by 7. 4-, 1. 7-, 13. 4-, 10. 5-, 17. 6-, and 15.2fold, respectively. After 4 months of vermicomposting, the earthworm treatments contained $60 \%$ of fungi, $80 \%$ of bacteria, $112 \%$ of actinobacteria, $86 \%$ of G+ bacteria, $73 \%$ of Gbacteria, and $71 \%$ of total microbial biomass compared to treatments without earthworms (Table 4). However, PWS $100 \%$ contained a greater number of microorganisms, except fungi, than the control treatment. Within treatments with and without earthworms, the greatest number of fungi, bacteria, actinobacteria, G+ bacteria, G- bacteria, and total microbial biomass was found in PWS 100\% without earthworms, sludge 100\% without earthworms, sludge 100\% with earthworms, PWS 100\% with earthworms, PWS 100\% with earthworms, and sludge $75 \%$ + PWS 25\% without earthworms, respectively.

Microorganism content in precomposted treatments at the process end was slightly greater (bacteria-410 $\mu \mathrm{g} / \mathrm{g}$, actinobacteria $-9 \mu \mathrm{g} / \mathrm{g}$, G+ bacteria-183 $\mu \mathrm{g} / \mathrm{g}, \mathrm{G}-$ bacteria$187 \mu \mathrm{g} / \mathrm{g}$, and total microbial biomass-508 $\mu \mathrm{g} / \mathrm{g}$ ), as shown

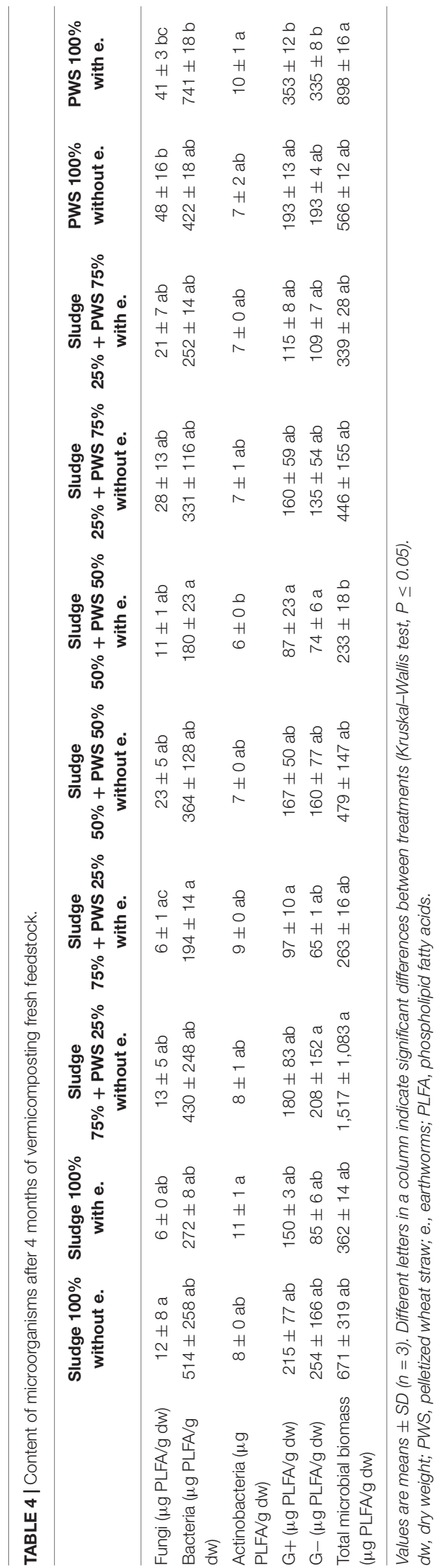




\section{Vermicomposting of precomposted feedstocks}
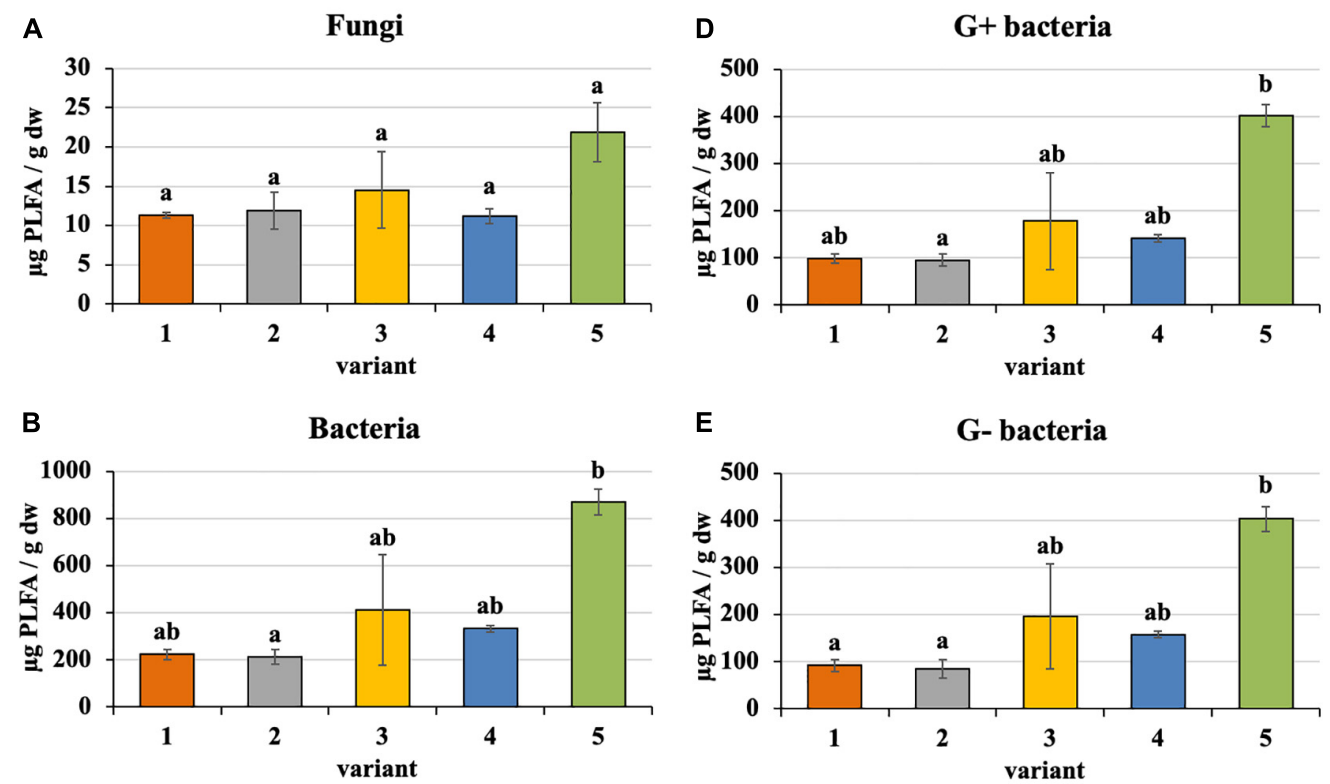

E

G- bacteria

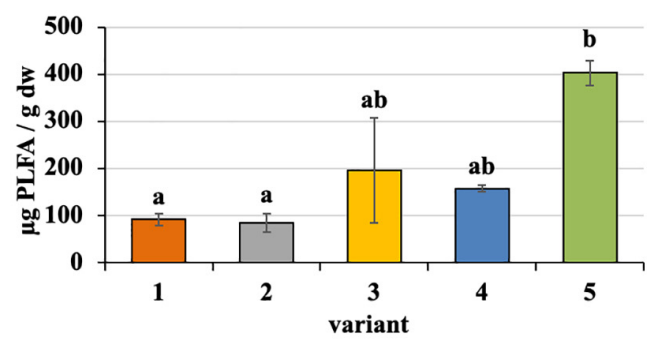

C

Actinobacteria

F

Total microbial biomass
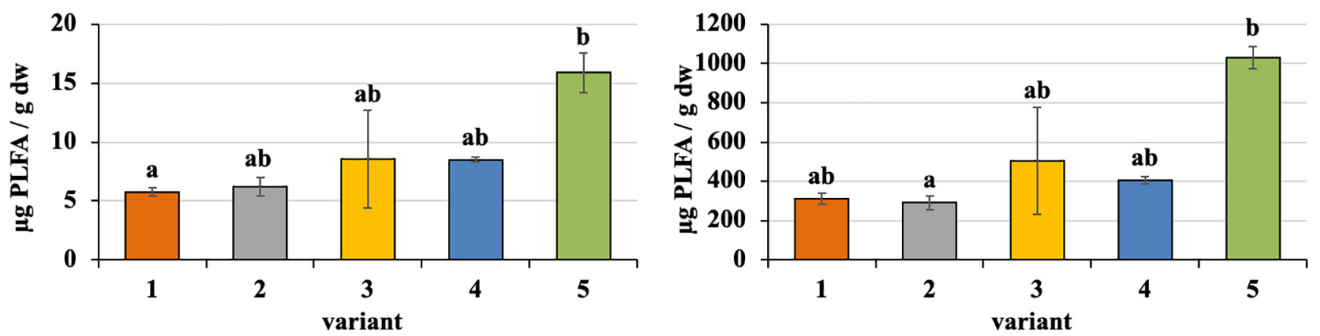

FIGURE 5 | Content of microorganisms after vermicomposting precomposted feedstock. Treatments: (1) sludge 100\% with earthworms, (2) sludge 75\% + PWS 25\% with earthworms, (3) sludge 50\% + PWS 50\% with earthworms, (4) sludge 25\% + PWS 75\% with earthworms, and (5) PWS 100\% with earthworms. Values are means $\pm \mathrm{SD}(n=3)$. Different letters indicate significant differences among treatments (Kruskal-Wallis test, $P \leq 0.05)$. PWS, pelletized wheat straw; PLFA, phospholipid fatty acids; dw, dry weight.

in Figure 5, than in the case of freshly used feedstocks described above (bacteria-328 $\mu \mathrm{g} / \mathrm{g}$, actinobacteria-8 $\mu \mathrm{g} / \mathrm{g}$, $\mathrm{G}+$ bacteria-160 $\mu \mathrm{g} / \mathrm{g}, \mathrm{G}-$ bacteria- $134 \mu \mathrm{g} / \mathrm{g}$, and total microbial biomass-419 $\mu \mathrm{g} / \mathrm{g}$ ). Fungi were exceptions (in precomposted treatments $-14 \mu \mathrm{g} / \mathrm{g}$ and in treatments with fresh feedstocks-17 $\mu \mathrm{g} / \mathrm{g})$. The greatest content of individual microorganism groups were unequivocally found in PWS 100\%, followed by sludge 50\% + PWS 50\%, sludge $25 \%+$ PWS $75 \%$, and almost identically sludge $100 \%$ and sludge $75 \%+$ PWS $25 \%$.

\section{DISCUSSION}

During sludge composting and treatments with its addition, there was a significant and permanent decrease in $\beta$-Dglucosidase activity. In the case of straw pellets, there was a reduced but constant enzyme activity because of slow degradation. Plant residues primarily composed of cellulose, hemicellulose, or lignin are difficult to biodegrade and increase composting time, which is associated with longer enzymatic activity (Hemati et al., 2021). Estrella-González et al. (2019) determined profiles of $\beta$-glucosidase, amylase, cellulase, and xylanase activities during large-scale composting of vegetable waste, urban solid waste, sewage sludges, agrifood waste, and olive oil mill wastewater. The results revealed very different profiles. The evolution profiles of the enzymes involved in the degradation of lignocellulosic fractions in sewage sludges coincided with greater biodegradation rates of these fractions at the process end. The $\beta$-D-glucosidase decrease in sewage sludge copied the trend we found. Unfortunately, it is not possible to compare specific values because we utilized the more effective and modern fluorescence method, and the previous study used classical colorimetric estimation of $\mathrm{p}$-nitrophenol released by $\mathrm{p}$-nitrophenyl- $\beta$-Dglucopiranoside hydrolysis.

The greatest acid phosphatase activity was found at composting beginning in $100 \%$ sewage sludge, which was 
because of the high phosphorus content in this feedstock. This statement is confirmed by Albrecht et al. (2010) who co-composted green waste and sewage sludge for 5 months. Acid phosphatase activities were high during the first month of composting and then declined. Large nutrient quantities stimulated the growth of total aerobic bacteria and subsequent phosphatase activity.

Ma et al. (2019) found that arylsulphatase content in sewage sludge $(75 \%)+$ sawdust $(25 \%)$ initially increased and subsequently decreased from the initial rate of 10.05 to $15.51 \mu \mathrm{mol} /(\mathrm{h} \times \mathrm{g})$ at the end of composting. By contrast, the arylsulphatase content in sewage sludge $(75 \%)+$ sawdust $(12.5 \%)+$ matured compost (12.5\%) decreased continuously. The arylsulphatase content in the matured compost treatment was significantly greater than in the treatment without matured compost at the mesophilic phase. After entering the thermophilic phase, the arylsulphatase content in sewage sludge $(75 \%)+$ sawdust $(12.5 \%)+$ matured compost (12.5\%) was significantly greater than that without matured compost, and this difference was maintained until the composting end $(P<0.05)$. Therefore, the arylsulphatase content increased during the mesophilic phase and decreased during the cooling phase when the matured compost was added. In our experiment, the arysulphatase activity increased after the $2^{\text {nd }}$ month of composting in the treatments with 50 and $75 \%$ straw pellets and in the case of the pellets themselves in the $2^{\text {nd }}$ half of the process. This may be because of the gradual release of organic sulfur from straw with the degradation of cellulose and other refractory organic matter, resulting in increased arylsulphatase content (Tejada et al., 2006).

Gea et al. (2007) co-composted sewage sludge with 30 and $50 \%$ fat addition. Lipase from a thermophilic composting environment showed a high stability for mesophilic temperature values and slightly alkaline $\mathrm{pH}$ values. The maximum lipolytic activity was observed at the thermophilic phase, which is consistent with our findings where the greatest lipase activity was during the first month of composting and then declined. Lipase activity in this period ranged from 3,300 to $5,000 \mu \mathrm{mol}$ MUFY $\mathrm{h}^{-1} \mathrm{~g}^{-1} \mathrm{dw}$, with the exception of sludge $25 \%+$ PWS $75 \%$ (9360 $\mu \mathrm{mol}$ MUFY $\mathrm{h}^{-1} \mathrm{~g}^{-1} \mathrm{dw}$ ), and decreased to $1,000 \mu \mathrm{mol}$ MUFY/h/g dw at composting end.

Chitinase activity varied greatly among treatments at the beginning of composting. The values were directly proportional to the proportion of sewage sludge. Poulsen et al. (2008) reported that chitinase activity was much greater in household waste compost $(3.97 \mu \mathrm{mol} 4 \mathrm{MU} / \mathrm{h} \times \mathrm{g}$ dry matter) than in garden/park compost $(0.46 \mu$ mol 4 $\mathrm{MU} / \mathrm{h} \times \mathrm{g}$ dry matter). Chitinase genes are found in a range of microorganisms, in particular actinomycetes, and in fungi (Krsek and Wellington, 2001). These organisms were apparently present and active to a greater extent during sludge composting and mixtures with a great proportion of this feedstock.

Cellobiohydrolase activity strongly correlated with $\beta$-Dglucosidase because they participated in carbonaceous substance decomposition, especially saccharides such as cellulose and cellobiose. The greatest activity of both enzymes was recorded in sludge $25 \%+$ PWS $75 \%$, especially in the first half of the composting. The sludge significantly supported and accelerated microorganism development and thus the decomposition of the above-mentioned substances in straw pellets. The activity of both enzymes was significantly greater compared to the straw pellets itself.

The profile of alanine and leucine aminopeptidase was different from those of other enzymes during composting. After 2 months of composting, there was an increase in enzymatic activity. This increase was greatest at 75 and $100 \%$ straw pellets. Thus, enzyme activity must have been related to terminal nitrogen release from alanine and leucine found in straw. For a detailed evaluation, it would be necessary to establish further experiments and also to monitor the amino acid content.

Similar to composting, the greatest enzymatic activity decrease occurred in the first half of vermicomposting. Straw is as an important bulking agent because it matures compost and vermicompost faster as evidenced by decreased enzymatic activities. A great proportion of straw pellets proved successful in vermicomposting coffee grounds (Hanc et al., 2021). The greatest earthworm number and biomass were in the treatment with $75 \%$ straw pellets. The experiment was operated in a system with continuous earthworm feeding. The following enzymatic activities were detected in the oldest layer (6 months) of this treatment: $\beta$-D-glucosidase$1,194 \mu \mathrm{mol} \mathrm{MUFG} / \mathrm{h} / \mathrm{g} \mathrm{dw}$, acid phosphatase-1,894 $\mu \mathrm{mol}$ MUFP/h/g dw, arylsulphatase-64 $\mu \mathrm{mol}$ MUFS/h/g dw, lipase-3,924 $\mu \mathrm{mol}$ MUFY/h/g dw, chitinase-207 $\mu \mathrm{mol}$ MUFN/h/g dw, cellobiohydrolase-105 $\mu \mathrm{mol} \quad \mathrm{MUFC} / \mathrm{h} / \mathrm{g}$ $\mathrm{dw}$, alanine aminopeptidase-46 $\mu \mathrm{mol} \mathrm{AMCA} / \mathrm{h} / \mathrm{g} \mathrm{dw}$, and leucine aminopeptidase-55 $\mu \mathrm{mol} \mathrm{AMCL} / \mathrm{h} / \mathrm{g} \quad \mathrm{dw}$. These values were greater than in the current study, which was due to a different processed raw material and technological procedure. During vermicomposting of sewage sludge and coffee grounds, lesser enzymatic activities were found in treatments with earthworms than those without earthworms. Similarly, Domínguez and Gómez-Brandón (2012) reported that earthworm activity greatly reduced protease and cellulase enzyme activities in comparison with the control. These findings are in agreement with the microbial activity data, which reinforces that a greater degree of stability was reached after the active vermicomposting phase. This is also related to the microbiota composition changes in the intestines of earthworms and vermicompost. Domínguez et al. (2021) utilized $16 \mathrm{~S}$ and ITS rRNA high-throughput sequencing to characterize bacterial and fungal community composition and structure during the gut-associated processes (GAP) and cast-associated processes of sewage sludge vermicomposting. The bacterial and fungal communities of earthworm casts were mainly composed of microbial taxa not found in the sewage sludge. Thus, most of the bacterial (96\%) and fungal (91\%) taxa in the sewage sludge were eliminated during vermicomposting, mainly through the GAP. Less microbial biomass, mainly fungi, was found in the earthworm treatments, which is consistent with the claim that fungi are a valuable food source 
(Zhang et al., 2000). Hřebečková et al. (2019) compared the enzymatic activity in three aged vermicompost types (from household biowaste, malt house sludge mixed with agricultural waste, and grape marc). The vermicomposting was conducted in large-scale heap systems with continuous earthworm feeding, which is applicable in practice. The greatest hydrolytic enzyme activity occurred in the vermicomposting process with household biowaste.

It is necessary to approach enzymatic activity values during composting and vermicomposting with caution. The enzymatic activity amount depends mainly on the feedstock types used as well as the maturity phase and the technological process used. In the case of vermicomposting, earthworm density and activity are important.

Further research should be focused on determining the effectiveness of sewage sludge composting and vermicomposting using other bulking agents. Furthermore, it would be appropriate to verify the materials used from the first half of the composting and vermicomposting period, when enzymatic activity was great. It would be interesting to use straw pellets, which are characterized by purity and whose enzymatic activity remained at greater values for a longer time period, both during composting and vermicomposting compared to other treatments. This could be used as a cheap way, for example, for the acceleration of biowaste decomposition and isolation of enzymes for the production of enzymatic preparations or for the revitalization of biologically inactive or contaminated soil.

\section{REFERENCES}

Albrecht, R., Petit, J. L., Calvert, V., Terrom, G., and Périssol, C. (2010). Changes in the level of alkaline and acid phosphatase activities during green wastes and sewage sludge co-composting. Bioresour. Technol. 101, 228-233. doi: 10.1016/j. biortech.2009.08.017

Almeida, R. F., Naves, E. R., and Mota, R. P. (2015). Soil quality: enzymatic activity of soil $\beta$-glucosidase. Glob. J. Agric. Res. Rev. 3, 146-150.

Baldrian, P. (2009). Microbial enzyme-catalyzed processes in soils and their analysis. Plant Soil Environ. 55, 370-378. doi: 10.17221/134/2009-pse

Błońska, E., Lasota, J., and Gruba, P. (2017). Enzymatic activity and stabilization of organic matter in soil with different detritus inputs. J. Soil Sci. Plant Nutr. 63, 242-247. doi: 10.1080/00380768.2017.1326281

Bradshaw, R. A. (2013). “Aminopeptidases," in Encyclopedia of Biological Chemistry II, eds W. J. Lennarz and M. D. Lane (Cambridge, MA: Academic Press), 97-99.

Domínguez, J., Aira, M., Crandall, K. A., and Pérez-Losada, M. (2021). Earthworms drastically change fungal and bacterial communities during vermicomposting of sewage sludge. Sci. Rep. 11:15556. doi: 10.1038/s41598-021-95099-z

Dominguez, J., and Edwards, C. A. N. (2011). "Relationship between composting and vermicomposting," in Vermiculture Technology: Earthworms, Organic Wastes, and Environmental Management, eds C. A. Edwards, N. Q. Arancon, and R. Sherman (Boca Raton, FL: CRC Press), 11-25.

Domínguez, J., and Gómez-Brandón, M. (2012). "Vermicomposting: composting with earthworms to recycle organic wastes," in Management of Organic Waste, eds S. Kumar and R. L. Sherman (London: IntechOpen), 29-48.

Estrella-González, M. J., Jurado, M. M., Suárez-Estrella, F., López, M. J., LópezGonzález, J. A., Siles-Castellano, A., et al. (2019). Enzymatic profiles associated with the evolution of the lignocellulosic fraction during industrial-scale composting of anthropogenic waste: comparative analysis. J. Environ. Manag. 248:109312. doi: 10.1016/j.jenvman.2019.109312

Eurostat (2021). Available online at: http://appsso.eurostat.ec.europa.eu/nui/ submitViewTableAction.do (accessed October 5, 2021).

\section{DATA AVAILABILITY STATEMENT}

The raw data supporting the conclusions of this article will be made available by the authors, without undue reservation.

\section{AUTHOR CONTRIBUTIONS}

$\mathrm{AH}$ contributed to conceptualization, methodology, investigation, writing, visualization, funding acquisition, formal analysis, and project administration. $\mathrm{BD}$ contributed to experiments, analyses, and data curation. $\mathrm{TH}$ contributed to data curation and formal analysis. All authors contributed to the article and approved the submitted version.

\section{FUNDING}

This work was supported by the Ministry of Agriculture of the Czechia under NAZV project no. QK1910095.

\section{ACKNOWLEDGMENTS}

We would like to thank Christina Baker Starrman (https:// cbsciedit.com/) for revision of the English text.

García-Gil, J. C., Plaza, C., Soler-Rovira, P., and Polo, A. (2000). Long-term effects of municipal solid waste compost application on soil enzyme activities and microbial biomass. Soil Biol. Biochem. 32, 1907-1913.

García-Sánchez, M., Stejskalová, T., García-Romera, I., Száková, J., and Tlustoš, P. (2017). Risk element immobilization/stabilization potential of fungaltransformed dry olive residue and arbuscular mycorrhizal fungi application in contaminated soils. J. Environ. Manag. 201, 110-119. doi: 10.1016/j.jenvman. 2017.06.036

Gea, T., Ferrer, P., Alvaro, G., Valero, F., Artola, A., and Sánchez, A. (2007). Cocomposting of sewage sludge:fats mixtures and characteristics of the lipases involved. Biochem. Eng. J. 33, 275-283. doi: 10.1016/j.bej.2006.11.007

Gómez-Brandón, M., Aira, M., Lores, M., and Domínguez, J. (2011). Epigeic earthworms exert a bottleneck effect on microbial communities through gut associated processes. PLoS One 6:e24786. doi: 10.1371/journal.pone.0024786

Gunjal, A. B., Waghmode, M. S., Patil, N. N., and Nawani, N. N. (2019). "Significance of soil enzymes in agriculture," in Smart Bioremediation Technologies, Microbial Enzymes, ed. P. Bhatt (Cambridge, MA: Academic Press), 159-168.

Hanc, A., Catkova, T., Kuzel, S., and Cajthaml, T. (2017). Dynamics of a verticalflow windrow vermicomposting system. Waste Manag. Res. 11, 1121-1128. doi: 10.1177/0734242X17725161

Hanc, A., Hrebeckova, T., Grasserova, A., and Cajthaml, T. (2021). Conversion of spent coffee grounds into vermicompost. Bioresour. Technol. 341:125925. doi: 10.1016/j.biortech.2021.125925

Hemati, A., Aliasgharzad, N., Khakvar, R., Khoshmanzar, E., Lajayer, B. A., and van Hullebusch, E. D. (2021). Role of lignin and thermophilic lignocellulolytic bacteria in the evolution of humification indices and enzymatic activities during compost production. Waste Manag. 119, 122-134. doi: 10.1016/j.wasman.2020. 09.042

Hřebečková, T., Wiesnerová, L., and Hanč, A. (2019). Changes of enzymatic activity during a large-scale vermicomposting process with continuous feeding. J. Clean. Prod. 239:118127. doi: 10.1016/j.jclepro.2019.118127 
Krsek, M., and Wellington, E. M. H. (2001). Assessment of chitin decomposer diversity within an upland grassland. Anton. Leeuw. 79, 261-267. doi: 10.1023/a: 1012043401168

Ma, C., Hu, B., Wei, M., Zhao, J., and Zhang, H. (2019). Influence of matured compost inoculation on sewage sludge composting: enzyme activity, bacterial and fungal community succession. Bioresour. Technol. 294:122165. doi: 10 . 1016/j.biortech.2019.122165

Manga, M., Camargo-Valero, M. A., Anthonj, C., and Evans, B. E. (2021). Fate of faecal pathogen indicators during faecal sludge composting with different bulking agents in tropical climate. Int. J. Hyg. Environ. Health 232:113670. doi: 10.1016/j.ijheh.2020.113670

Mondini, C., Fornasier, F., and Sinicco, T. (2004). Enzymatic activity as a parameter for the characterization of the composting process. Soil Biol. Biochem. 36, 1587-1594. doi: 10.1016/j.soilbio.2004.07.008

Nabarlatz, D., Stüber, F., Font, J., Fortuny, A., Fabregat, A., and Bengoa, C. (2012). Extraction and purification of hydrolytic enzymes from activated sludge. Resour. Conserv. Recyc. 59, 9-13. doi: 10.1016/j.resconrec.2011. 06.017

Nomenclature Committee of the International Union of Biochemistry and Molecular Biology [NC-IUBMB] (2021). Available online at: https://iubmb. qmul.ac.uk/enzyme/ (accessed October 1, 2021).

Poulsen, P. H. B., Møller, J., and Magid, J. (2008). Determination of a relationship between chitinase activity and microbial diversity in chitin amended compost. Bioresour. Technol. 99, 4355-4359. doi: 10.1016/j.biortech.2007.08.042

Robledo-Mahón, T., Gómez-Silván, C., Andersen, G. L., Calvo, C., and Aranda, E. (2020). Assessment of bacterial and fungal communities in a full-scale thermophilic sewage sludge composting pile under a semipermeable cover. Bioresour. Technol. 298:122550. doi: 10.1016/j.biortech.2019.122550

Sethupathy, A., Arun, C., Sivashanmugam, P., and Ranjith Kumar, R. (2020). Enrichment of biomethane production from paper industry biosolid using ozonation combined with hydrolytic enzymes. Fuel 279:118522. doi: 10.1016/ j.fuel.2020.118522

Štursová, M., and Baldrian, P. (2011). Effects of soil properties and management on the activity of soil organic matter transforming enzymes and the quantification of soil-bound and free activity. Plant Soil 338, 99-110. doi: 10.1007/s11104-0100296-3

Tejada, M., Garcia, C., Gonzalez, J. L., and Hernandez, M. T. (2006). Use of organic amendment as a strategy for saline soil remediation: influence on the physical, chemical and biological properties of soil. Soil Biol. Biochem. 38, 1413-1421. doi: 10.1016/j.soilbio.2005.10.017

Tzelepis, G., and Karlsson, M. (2021). "The fungal chitinases," in Encyclopedia of Mycology, eds O. Zaragoza and A. Casadevall (Amsterdam: Elsevier Science Publishing Co Inc), 23-31.

Uzarowicz, Ł, Wolińska, A., Błońska, E., Szafranek-Nakonieczna, A., Kuźniar, A., Słodczyk, Z., et al. (2020). Technogenic soils (Technosols) developed from mine spoils containing Fe sulphides: microbiological activity as an indicator of soil development following land reclamation. Appl. Soil Ecol. 156:103699. doi: 10.1016/j.apsoil.2020.103699

Villeneuve, P., Muderhwa, J. M., Graille, J., and Haas, M. J. (2000). Customizing lipases for biocatalysis: a survey of chemical, physical and molecular biological approaches. J. Mol. Catal. B Enzym. 9, 113-148. doi: 10.1016/S1381-1177(99) 00107-1

Wang, K., Ma, X., Yin, X., Wu, C., Wang, Z., Wu, Y., et al. (2021). Difference and interplay of microbial communities, metabolic functions, trophic modes and influence factors between sludge and bulking agent in a composting matrix. Bioresour. Technol. 336:125085. doi: 10.1016/j.biortech.2021.125085

Yuan, J., Chadwick, D., Zhang, D., Li, G., Chen, S., Luo, W., et al. (2016). Effects of aeration rate on maturity and gaseous emissions during sewage sludge composting. Waste Manag. 56, 403-410. doi: 10.1016/j.wasman.2016.07.017

Zhang, B., Li, G., Shen, T., Wang, J., and Sun, Z. (2000). Changes of microbial biomass $\mathrm{C}, \mathrm{N}$, and $\mathrm{P}$ and enzyme activities in soil incubated with the earthworms Metaphire guillelmi or Eisenia fetida. Soil Biol. Biochem. 32, 20552062. doi: 10.1016/S0038-0717(00)00111-5

Zhang, Q., Hu, J., Lee, D. J., Chang, Y., and Lee, Y. J. (2017). Sludge treatment: current research trends. Bioresour. Technol. 243, 1159-1172. doi: 10.1016/j. biortech.2017.07.070

Zheng, M. M., Wang, C., Li, W. X., Guo, L., Cai, Z. J., Wang, B. R., et al. (2021). Changes of acid and alkaline phosphatase activities in long-term chemical fertilization are driven by the similar soil properties and associated microbial community composition in acidic soil. Eur. J. Soil Biol. 104:103312. doi: 10. 1016/j.ejsobi.2021.103312

Zoglowek, M., Lübeck, P. S., Ahring, B. K., and Lübeck, M. (2015). Heterologous expression of cellobiohydrolases in filamentous fungi - an update on the current challenges, achievements and perspectives. Process Biochem. 50, 211-220. doi: 10.1016/j.procbio.2014.12.018

Conflict of Interest: The authors declare that the research was conducted in the absence of any commercial or financial relationships that could be construed as a potential conflict of interest.

Publisher's Note: All claims expressed in this article are solely those of the authors and do not necessarily represent those of their affiliated organizations, or those of the publisher, the editors and the reviewers. Any product that may be evaluated in this article, or claim that may be made by its manufacturer, is not guaranteed or endorsed by the publisher.

Copyright (c) 2022 Hanc, Dume and Hrebeckova. This is an open-access article distributed under the terms of the Creative Commons Attribution License (CC BY). The use, distribution or reproduction in other forums is permitted, provided the original author(s) and the copyright owner(s) are credited and that the original publication in this journal is cited, in accordance with accepted academic practice. No use, distribution or reproduction is permitted which does not comply with these terms. 